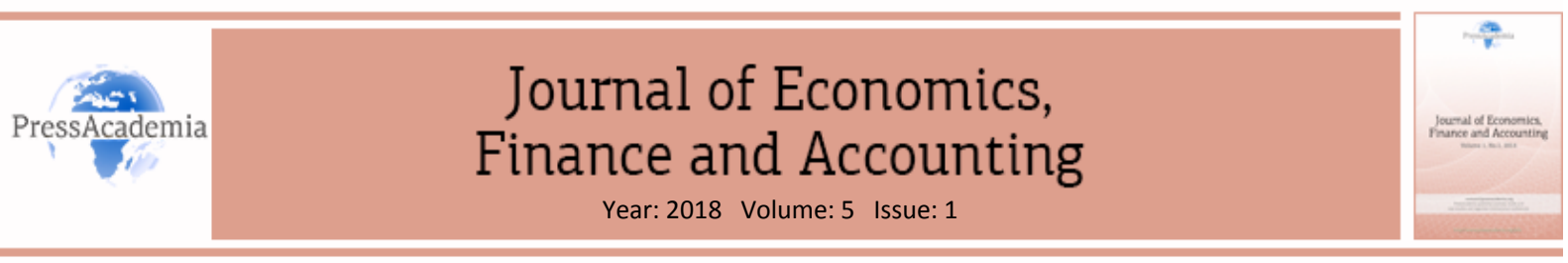

\title{
INTERNATIONAL ECONOMIC INTEGRATIONS FOR PARTIES OR NON-PARTIES COUNTRIES: TURKEY'S STATE IN THE EXAMPLES OF TTIP, CETA AND CPTPP
}

\author{
DOI: 10.17261/Pressacademia.2018.784 \\ JEFA- V.5-ISS.1-2018(6)-p.58-78 \\ Sibel Caskurlu ${ }^{1}$ \\ ${ }^{1}$ Gazi University, Faculty of Economics and Administrative Science, Department of Economics, Beşevler, Ankara, Turkey. \\ erencas@gmail.com, ORCID: 0000-0001-6394-8198
}

To cite this document

Caskurlu, S., (2018). International economic integrations for parties or non-parties countries: turkey's state in the examples of TTIP, CETA and CPTPP, Journal of Economics, Finance and Accounting (JEFA), V.5, Iss.1, p.58-78

Permemant link to this document: http://doi.org/10.17261/Pressacademia.2018.784

Copyright: Published by PressAcademia and limited licenced re-use rights only.

\begin{abstract}
Purpose - Growing markets with the emergence of trade in the direction of meeting the needs have manifested itself in the widespread of international trade with the increasing influence of the world population and globalization. As a result of these developments, trade volumes between countries have increased. On the other hand, the rapid change and growth experienced in world trade push the countries into an effort to manage and direct foreign trade as integrated with each other as far as their sovereignty is concerned. This effort exposes economic integration activities. In any case, integration creates different effects in terms of the countries inside and outside. Methodology - In this study the effects of comprehensive free trade agreements on Turkey are investigated both in terms of foreign trade and value -added test.

Findings - In this study the effects of integrations which Turkey is a member and is not are studied. If some additional measures and specific strategies are not executed, it will inevitably arise that Turkey would be affected negatively from the economic integrations which are involved.

Conclusion - Turkey's trade surplus has a potential to achieve but there arises a need for caution in terms of the conduct of trade policy.

Keywords: Economic integration, free trade agreements, rate of exports meet imports, value added trade, export composition JEL Codes: F53, F62, F15

\section{TARAF OLAN VE OL(A)MAYAN ÜLKELER AÇISINDAN ULUSLARARASI IKTISADI BÜTÜNLEŞMELER: TTIP, CETA VE/VEYA CPTPP ÖRNEKLERINDE TÜRKIYENIN DURUMU}

\section{ÖZET}

Amaç - Ihtiyaçların karşılanması doğrultusunda ortaya çıkan ticaret olgusu ile büyüyen piyasalar, artan dünya nüfusu ve küreselleşmenin de etkileriyle uluslararası ticaretin yaygınlaşması şeklinde kendini göstermiş̧ir. Bu gelişmelerin sonucu olarak ülkeler arası ticaret hacimleri artmıştır. Öte yandan, dünya ticaretinde yaşanan hızlı değişim ve büyüme, ülkeleri kendi egemenlik alanlarında olduğu kadar birbirleriyle de entegre olarak dış ticareti yönetme ve yönlendirme çabası içine itmektedir. Söz konusu çaba iktisadi bütünleşme faaliyetlerini ortaya çıkarmaktadır. Bütünleşme hangi biçimde olursa olsun içinde ve dışında olan ülkeler açısından farklı etkiler yaratmaktadır.

Methodoloji - Bu çalışmada büyük aktörlü STA'ların etkisi, Türkiye açısından hem dış ticaret hem de katma değer sınaması ile araştıııımıştır. Bulgular- Çalışmada Türkiye'nin üye olduğu ve ol(a)madığı bütünleşme faaliyetlerinin etkileri incelenmiştir. Yapılan incelemede eğer ek önlemler alınmaz ve stratejiler yürütülmez ise Türkiye'nin dahil olduğu iktisadi bütünleşmelerden dahi olumsuz olarak etkilenmesi kaçınılmaz olacağı ortaya çıkmaktadır.

Sonuç- Türkiye'nin dış ticaret fazlası elde etmek için potansiyeli bulunmakta ancak dış ticaret politikasının yürütülmesi açısından dikkatli olunması gereği ortaya çıkmaktadır.

Anahtar Kelimeler: İktisadi bütünleşme, serbest ticaret anlaşmaları, ihracatın ithalatı karşılama oranı, katma değer ticareti, ihracat kompozisyonu

JEL Codes: F53, F62, F15 


\section{GiRiş}

Ekonomik bütünleşmeler farklı biçimlerde gerçekleştirilmekte ve başta ekonomik olmak üzere gerçekleştirilen bütünleşme biçimine göre siyasal ve sosyal etkiler yaratabilmektedir. Bütünleşme durumunun dolaylı ve/veya doğrudan kayıp ve kazançlarının belirlenmesi gerekmektedir. En dar kapsamlı olanlarında dahi bütünleşme uygulamalarının önemli ölçüde etkilediği temel parametrelerden biri dış ticarettir. Dış ticaretin döviz kazandırıcı etkisi, ülke içinde döviz yükümlülüklerinin karşılanabilmesi açısından önemlidir. Bunun ötesinde makroekonomi açısından cari açı̆̆ın mal hareketleri kısmından doğabilecek ve tüm ekonomiye yayılacak olumsuz etkilerinin önlenmesi açısından da dikkate alınmalıdır. Serbest ticaret anlaşmalarının taraf ülkeler açısından birbirlerinden gerçekleştirilecek mal ve hizmet alım ve satım işlemlerinde gerek faaliyetlerin kolaylaştırılması gerekse gümrük vergisi, vergiye eş etkili düzenlemeler, tarifeler vb. yükümlülüklerin azaltılması ve/veya kaldırılması şeklinde avantajları bulunmaktadır. Dünya ekonomik sahnesinde belli bir dönemdir süregelen söz konusu anlaşmalar, son yıllarda özellikle dünya pazarında önemli paya ve güçlü ekonomik yapılara sahip ülkeler arasında yapılagelmektedir. Bu durum anlaşmalara taraf olmayan ülkeler ve taraf olmamakla birlikte söz konusu anlaşmaları gerçekleştiren güçlü ekonomik aktör ülkelerle başka bir dizi taahhüt altına girmiş dolayısıyla anlaşmalara dezavantajlı bir şekilde uymak zorunda olan ülkeler açısından çok büyük sorunlara yol açmaktadır.

Ekonomik yapısına göre dış ticaret faaliyetlerinden kazançlı çıkma uğraşııında olan, dışsatım yapabilmek için dışalım yapmak zorunda kalan ve dış ticaret faaliyeti dışalım ağırlığının öncelikle cari açık ve buradan da bütçe açıklarına kadar giden bir sorunlar zincirine sahip ülkelerin bir de büyük çaplı ticaret anlaşmalarının olumsuzluklarına maruz kalmaları var olan kırılgan yapılarını derinleştirmektedir. Bu çalışmada bütünleşme biçimlerinin Türkiye açısından genel durumu incelendikten sonra önemli bir ekonomik bütünleşme biçimi olan serbest ticaret anlaşmalarının (STA) ve özellikle son dönemde dünya ekonomik ilişkileri bağlamında gelişmiş ülkeler arasında gerçekleştirilmesine yönelik müzakere edilen (TTIP) ve gerçekleştirilen (CETA, CPTTP) STA'ların Türkiye açısından ne tür olumlu ve olumsuz yönleri olabileceği / olduğu analiz edilmeye çalışılmıştır. Türkiye açısından gelişmekte olan ülke karakteristiği sergilemesi bağlamında dış ticaret faaliyetlerinin ithalat yönlü olduğu görülmektedir ve bu durum zaten bilinmektedir. İçeriği dış ticaret ürün kompozisyonu çalışmalarına konu edilmesi gereken son dönemlerdeki yapı, ithal girdilerin kullanılmasının yanı sıra ihracatta az da olsa katma değer yaratmanın öneminin algılandığı bir hale bürünmüştür. Ancak katma değerde ithal girdi halen yüksektir. Buna daha fazla dikkat edilmesi gerekmektedir. Bunun yanı sıra dış ticaret faaliyetlerini içsel yapısından ziyade etkileyecek çok temel bir unsurda önemli risklerin olduğudur. $A B$ ile içinde olunan GB kaynaklı olarak ihracat çeşitliliğinin arttığı görülmektedir. Ancak GB'den dolayı $A B^{\prime}$ nin ikili ticaret anlaşmasının bulunduğu pek çok ülke ile dış ticaretimiz rekabet dezavantajı ile gerçekleşmektedir. Bu ülkeler arasında önemli ekonomik aktörler bulunmakta ve bunlar da kendi aralarında bütünleşmelere gitmektedir. Özellikle bütün dikkat TTIP gibi henüz imzalanmamış ancak imzalanma olasılığı bulunan kapsamlı bir ticaret anlaşmasının risklerine çevrilmişken, imzalanan CETA ve CPTPP gibi anlaşmaların Türkiye dış ticareti ve bunun üzerinden makroekonomik yapı üzerindeki önemli derecede olumsuz etkilerinin stratejik olarak göz önüne alınması bir zorunluluktur.

\section{LITERATÜR INCELEME}

\section{1. İktisadi Bütünleşme Biçimleri: Genel Açıklamalar, Tanım ve Evreler}

Uluslararası iktisadi ilişkiler çerçevesinde ülkeler arasındaki bütünleşmeyi sağlamak açısından gerçekleştirilen temel faaliyetlerden biri serbest ticaret anlaşmaları olmaktadır. İktisadi bütünleşmelerde, ülke ekonomileri çeşitli uygulamalarla bir araya gelmekte ve bir ekonomik ilişki alanı oluşturmaktadır (Ertürk, 2010: 140). Söz konusu bütünleşmeler biçimleri nasııl olursa olsun taraf ülkeler açısından çeşitli bağlılıklar ve taahhütler içermektedir. İktisadi bütünleşme biçimleri şu şekilde sıralanarak açıklanabilir (Ünsal, 2005: 409-411):

- Tercihli ticaret anlaşmaları: Anlaşmayı gerçekleştiren ülkelerin birbirlerine yönelik ticari sınırlandırmaları karşııklı olarak azaltılır.

- Serbest ticaret bölgeleri: Ülkelerin birbirlerine yönelik ticari sınırlandırmaları karşııklı olarak kaldırılır.

- Gümrük birlikleri: Ülkelerin birbirlerine olan ticari sınırlandırmaları kaldırılır ve taraf olmayan ülkelere karşı ortak ticaret politikası uygulanır.

- Ortak pazarlar: Ülkelerin birbirlerine olan ticari sınırlandırmaları kaldırılır, taraf olmayan ülkelere karşı ortak ticaret politikası uygulanır ve üretim faktörlerinin serbest dolanımı sağlanır.

- İktisadi birlikler: Ülkelerin birbirlerine olan ticari sınırlandırmaları kaldırılır, taraf olmayan ülkelere karşı ortak ticaret politikası uygulanır, üretim faktörlerinin serbest dolanımı sağlanır ve ortak para birimi ile iktisat politikaları uygulanır.

\subsection{Türkiye'nin Dış Ticaretini Etkileyen Bağımlılıklar ve Taahhütler}

Bu başlık altında iktisadi bütünleşme biçimleri açısından yukarıdaki sırasıyla Türkiye dış ticaretini etkileyen unsurlar ele alınacaktır. 


\subsubsection{Türkiye'nin Gerçekleştirdiği Serbest Ticaret Anlaşmaları}

Uluslararası iktisadi ilişkiler çerçevesinde Türkiye'nin uluslararası rekabette üstünlüğün elde edilmesine yönelik ve farklı coğrafyalarda yeni pazarlara ulaşım açısından serbest ticaret anlaşmalarını gerçekleştirdiği görülmektedir (Atılgan ve Kanat, 2007: 101). Serbest ticaret anlaşmaları gerçekleştirilmesinin gerekçeleri şu şekilde belirtilmiştir (T.C. Ekonomi Bakanlığı, Serbest Ticaret Anlaşmaları Portalı,

http://www.ekonomi.gov.tr/portal/content/conn/UCM/path/Contribution\%20Folders/web):

$$
\begin{aligned}
& \text {-Ülkelerin tercihli ticaret olanaklarından yararlanabilmesi } \\
& \text {-Yeni Pazar arayışlarının gerçekleştirilebilmesi } \\
& \text {-Ülkelerin rekabet fırsat eşitliğini sağlayabilmeleri } \\
& \text {-Karşılıklı yatırımlar ve ortak girişimlerin gerçekleştirilebilmesi }
\end{aligned}
$$

Ifade edilen bu gerekçeler çerçevesinde ve Avrupa Birliği ile gerçekleştirilmiş olan Gümrük Birliği dolayısıyla Türkiye serbest ticaret anlaşmaları yapmaktadır. Gümrük Birliği çerçevesinde birlik içindeki ülkeler arasında malların serbest dolaşımı, ülkeler arasında ortak ticaret ve rekabet politikaların oluşturulması söz konusu iken, serbest ticaret anlaşmalarında ise menşei kurallarına göre ticaret rejimlerinden yararlanma durumu bulunmakta, ortak ticaret ve rekabet politikaları uygulama zorunluluğu olmamakta ve gümrük tarifeleri uygulanmaktadır (T.C. Ekonomi Bakanlığı, Serbest Ticaret Anlaşmaları Portalı, http://www.ekonomi.gov.tr/portal/content/conn/UCM/path/Contribution\%20Folders/web).

Buradan hareketle Türkiye'nin Gümrük Birliği çerçevesinde $A B^{\prime}$ nin serbest ticaret anlaşmaları imzaladığı ülkelerle arasında kendi yararını korumak adına söz konusu anlaşmaları düzenlediği görülmektedir. Ancak daha sonra da ifade edileceği üzere, Türkiye'nin $A B^{\prime}$ nin ticaret anlaşması imzaladığı ülkelerin bütünüyle düzenlenmiş ticaret anlaşması bulunmamaktadır. Bu durum Türkiye'nin anlaşma imzalamadığı ancak $A B^{\prime}$ nin anlaşmasının olduğu ülkeler ile $A B$ arasındaki şartlara Türkiye'nin uyma zorunluluğunu ortaya çıkarmaktadır.

\begin{tabular}{|c|c|c|c|}
\hline & \multirow{2}{*}{ ÜLKE } & \multicolumn{2}{|r|}{ Anlaşmanın } \\
\hline & & İmza Tarihi & Yürürlüğe Girişi \\
\hline 1 & $\begin{array}{l}\text { EFTA (İsviçre-Norveç- } \\
\text { İzlanda ve Lihtenştayn) } \\
\text { (Yürürlük Tarihi:01.04.1992) }\end{array}$ & 10.12.1991 & 1.04.1992 \\
\hline 2 & İsrail & 14.03.1996 & 1.05 .1997 \\
\hline 3 & Makedonya & 7.09.1999 & 1.09 .2000 \\
\hline 4 & Bosna ve Hersek & 3.07.2002 & 01.07 .2003 \\
\hline 5 & Filistin & 20.07.2004 & 1.06 .2005 \\
\hline 6 & Tunus & 25.11 .2004 & 1.07.2005 \\
\hline 7 & Fas & 7.04.2004 & 1.01 .2006 \\
\hline 8 & *Suriye & 22.12 .2004 & $\begin{array}{l}\text { *Türkiye ile Suriye Arasında Serbest Ticaret Alanı Tesis Eden Ortaklık } \\
\text { Anlaşması } 6 \text { Aralık } 2011 \text { tarihinde karşılıklı olarak askıya alınmıştır. }\end{array}$ \\
\hline 9 & Misır & 27.12.2005 & 1.03 .2007 \\
\hline 10 & Arnavutluk & 22.12 .2006 & 1.05 .2008 \\
\hline
\end{tabular}

Tablo 1'de yürürlüğe girmiş, müzakereleri tamamlanmış ancak henüz uygulamaya geçmeyen ve yürürlüğe girmek için çeşitli işlemlerin yapılması beklenen serbest ticaret anlaşmalarının listesi bulunmaktadır.

Tablo 1: 1991 - 2017 Tarihleri Arasında İmzalanan Serbest Ticaret Anlaşmaları 


\begin{tabular}{|c|c|c|c|}
\hline 11 & Gürcistan & 21.11.2007 & 1.11 .2008 \\
\hline 12 & Karadağ & 26.11 .2008 & 1.03 .2010 \\
\hline 13 & Sirbistan & 1.06 .2009 & 1.09 .2010 \\
\hline 14 & Şili & 14.07.2009 & 1.03.2011 \\
\hline 15 & Ürdün & 1.12.2009 & 1.03 .2011 \\
\hline 16 & Lübnan & 14.07.2009 & $\begin{array}{l}\text { Lübnan tarafının, iç onay sürecini tamamlamasına müteakip yürürlüğe } \\
\text { girecektir. }\end{array}$ \\
\hline 17 & Moritus & 9.09 .2011 & 1.05 .2013 \\
\hline 18 & Güney Kore & 1.08 .2012 & 1.05 .2013 \\
\hline 19 & Malezya & 17.04 .2014 & 1.08 .2015 \\
\hline 20 & Kosova & 28.09 .2013 & $\begin{array}{l}\text { Her iki tarafın iç onay süreçlerinin tamamlanmasına müteakip yürürlüğe } \\
\text { girecektir. }\end{array}$ \\
\hline 21 & Moldova & 11.09 .2014 & 1.11.2016 \\
\hline 22 & Faroe Adaları & 16.12.2014 & 1.10 .2017 \\
\hline 23 & Singapur & 14.11.2016 & 1.10.2017 \\
\hline 24 & Gana & & $\begin{array}{l}\text { Müzakereleri tamamlanmıştır. Yakın zamanda imzalanması } \\
\text { beklenmektedir. }\end{array}$ \\
\hline
\end{tabular}

Kaynak:http://www.orgtr.org/tr/serbest-ticaret-anlasmasi-sta-imzaladigimiz-ulkeler-ve-yururluk-tarihleri; http://www.ekonomi.gov.tr

Türkiye'nin en son Ekim 2017 tarihi olmak üzere fiili olarak 24 ülke ile serbest ticaret anlaşması gerçekleştirdiği Tablo 1'de görülmektedir. Bu anlaşmalardan üçü (Kosova, Gana ve Lübnan) beklemededir. Bir anlaşma da (Suriye) karşılıklı olarak askıya alınmıştır. Tablo 2'de ise Avrupa Birliği tarafından gerçekleştirilen serbest ticaret anlaşmaları görülmektedir.

Tablo 2: Avrupa Birliği Serbest Ticaret Anlaşmalarının Listesi

\begin{tabular}{|c|c|c|c|c|c|}
\hline Serbest Ticaret Anlaşması & Kapsam & $\begin{array}{l}\text { Anlaşama } \\
\text { Biçimi }\end{array}$ & İmzalandı̆̆ı̆ Tarih & Yürürlük Tarihi & Durum \\
\hline KANADA & Mal ve Hizmet & STA ve ÇED & 19-Sep-2017 & 21-Sep-2017 & Yürürlükte \\
\hline $\begin{array}{l}\text { SADC } \\
\text { Southern African } \\
\text { Development Community } \\
\text { Angola, Mozambique, } \\
\text { Tanzania as well as } \\
\text { Botswana, Lesotho, } \\
\text { Namibia, Swaziland }\end{array}$ & Mal & STA & 03-Apr-2017 & 10-Oct-2016 & Yürürlükte \\
\hline Ghana & Mal & STA & 03-Apr-2017 & 15-Dec-2016 & Yürürlükte \\
\hline Colombia and Peru - & Mal ve Hizmet & STA ve ÇED & 2.Mar.17 & 01-Jan-2017 & Yürürlükte \\
\hline
\end{tabular}




\begin{tabular}{|c|c|c|c|c|c|}
\hline Accession of Ecuador & & & & & \\
\hline Georgia & Mal ve Hizmet & STA ve ÇED & 02-Jul-2014 & 01-Sep-2014 & Yürürlükte \\
\hline Ukraine & Mal ve Hizmet & STA ve ÇED & 01-Jul-2014 & 23-Apr-2014 & Yürürlükte \\
\hline Moldova, Republic of & Mal ve Hizmet & STA ve ÇED & 30-Jun-2014 & 01-Sep-2014 & Yürürlükte \\
\hline EU (28) Enlargement & Mal ve Hizmet & STA ve ÇED & 25-Apr-2013 & 01-Jul-2013 & Yürürlükte \\
\hline Central America & Mal ve Hizmet & STA ve ÇED & 26-Feb-2013 & 01-Aug-2013 & Yürürlükte \\
\hline $\begin{array}{l}\text { Colombia and Peru and } \\
\text { Ecuador }\end{array}$ & Mal ve Hizmet & STA ve ÇED & 26-Feb-2013 & 1.Mar.13 & Yürürlükte \\
\hline $\begin{array}{l}\text { Eastern and Southern Africa } \\
\text { States Interim EPA }\end{array}$ & Mal & STA & 09-Feb-2012 & 14.May.12 & Yürürlükte \\
\hline Papua New Guinea / Fiji & Mal & STA & 18-Oct-2011 & 20-Dec-2009 & Yürürlükte \\
\hline Korea, Republic of & Mal ve Hizmet & STA ve ÇED & 07-Jul-2011 & 01-Jul-2011 & Yürürlükte \\
\hline Serbia & Mal ve Hizmet & STA ve ÇED & $\begin{array}{l}\text { 31-May-2010(G) / 20- } \\
\text { Dec-2013(S) }\end{array}$ & $\begin{array}{l}\text { 01-Feb-2010(G) / 01- } \\
\text { Sep-2013(S) }\end{array}$ & Yürürlükte \\
\hline San Marino & Mal & GB & 24-Feb-2010 & 01-Apr-2002 & Yürürlükte \\
\hline Cameroon & Mal & STA & 24-Sep-2009 & 04-Aug-2014 & Yürürlükte \\
\hline Côte d'Ivoire & Mal & STA & 11-Dec-2008 & 03-Sep-2016 & Yürürlükte \\
\hline $\begin{array}{l}\text { CARIFORUM States EPA } \\
\text { The Caribbean Community + } \\
\text { Dominic Republican }\end{array}$ & Mal ve Hizmet & STA ve ÇED & 16-Oct-2008 & 01-Nov-2008 & Yürürlükte \\
\hline Bosnia and Herzegovina & Mal ve Hizmet & STA ve ÇED & $\begin{array}{l}\text { 11-Jul-2008(G) / 12-Jan- } \\
2016(S)\end{array}$ & $\begin{array}{l}\text { 01-Jul-2008(G) / 01- } \\
\text { Jun-2015(S) }\end{array}$ & Yürürlükte \\
\hline Montenegro & Mal ve Hizmet & STA ve ÇED & $\begin{array}{l}\text { 16-Jan-2008(G) / 18-Jun- } \\
2010(S)\end{array}$ & $\begin{array}{l}\text { 01-Jan-2008(G) / 01- } \\
\text { May-2010(S) }\end{array}$ & Yürürlükte \\
\hline Albania & Mal ve Hizmet & STA ve ÇED & $\begin{array}{l}\text { 07-Mar-2007(G) / 07- } \\
\text { Oct-2009(S) }\end{array}$ & $\begin{array}{l}\text { 01-Dec-2006(G) / 01- } \\
\text { Apr-2009(S) }\end{array}$ & Yürürlükte \\
\hline Algeria & Mal & STA & 24-Jul-2006 & 01-Sep-2005 & Yürürlükte \\
\hline Egypt & Mal & STA & 03-Sep-2004 & 01-Jun-2004 & Yürürlükte \\
\hline Chile & Mal ve Hizmet & STA ve ÇED & $\begin{array}{l}\text { 03-Feb-2004(G) / 28- } \\
\text { Oct-2005(S) }\end{array}$ & $\begin{array}{l}\text { 01-Feb-2003(G) / 01- } \\
\text { Mar-2005(S) }\end{array}$ & Yürürlükte \\
\hline Lebanon & Mal & STA & 26.May.03 & 1.Mar.03 & Yürürlükte \\
\hline Jordan & Mal & STA & 17-Dec-2002 & 1.May.02 & Yürürlükte \\
\hline $\begin{array}{l}\text { The former Yugoslav } \\
\text { Republic of Macedonia }\end{array}$ & Mal ve Hizmet & STA ve ÇED & $\begin{array}{l}\text { 23-Oct-2001(G) / 02- } \\
\text { Oct-2009(S) }\end{array}$ & $\begin{array}{l}\text { 01-Jun-2001(G) / 01- } \\
\text { Apr-2004(S) }\end{array}$ & Yürürlükte \\
\hline South Africa & Mal & STA & 02-Nov-2000 & 01-Jan-2000 & Yürürlükte \\
\hline Morocco & Mal & STA & $13-O c t-2000$ & 1.Mar.00 & Yürürlükte \\
\hline Israel & Mal & STA & 20-Sep-2000 & 01-Jun-2000 & Yürürlükte \\
\hline Mexico & Mal ve Hizmet & STA ve ÇED & $\begin{array}{l}\text { 25-Jul-2000(G) / 21-Jun- } \\
2002(S)\end{array}$ & $\begin{array}{l}\text { 01-Jul-2000(G) / 01- } \\
\text { Oct-2000(S) }\end{array}$ & Yürürlükte \\
\hline Tunisia & Mal & STA & 15-Jan-1999 & 1.Mar.98 & Yürürlükte \\
\hline Andorra & Mal & GB & 23-Feb-1998 & 01-Jul-1991 & Yürürlükte \\
\hline Palestinian Authority & Mal & STA & 29.May.97 & 01-Jul-1997 & Yürürlükte \\
\hline Faroe Islands & Mal & STA & 17-Feb-1997 & 01-Jan-1997 & Yürürlükte \\
\hline Turkey & Mal & GB & 22-Dec-1995 & 01-Jan-1996 & Yürürlükte \\
\hline Syria & Mal & STA & 15-Jul-1977 & 01-Jul-1977 & Yürürlükte \\
\hline Norway & Mal & STA & 13-Jul-1973 & 01-Jul-1973 & Yürürlükte \\
\hline Iceland & Mal & STA & 24-Nov-1972 & 01-Apr-1973 & Yürürlükte \\
\hline Switzerland - Liechtenstein & Mal & STA & 27-Oct-1972 & 01-Jan-1973 & Yürürlükte \\
\hline $\begin{array}{l}\text { Overseas Countries and } \\
\text { Territories (OCT) }\end{array}$ & Mal & STA & 14-Dec-1970 & 01-Jan-1971 & Yürürlükte \\
\hline
\end{tabular}

Kaynak: http://rtais.wto.org/UI/PublicAllRTAList.aspx

Not: STA: Serbest Ticaret Anlaşması, ÇED: Çevre Etki Değerlendirme Anlaşması, GB: Gümrük Birliği

Tablo 2'de yer alan ülkelerin bazıları ile Türkiye'nin serbest ticaret anlaşması bulunmaktadır. Diğer bir ifadeyle Türkiye ile serbest ticaret anlaşması imzalayan tüm ülkeler aynı zamanda $A B$ ile anlaşma imzalamışlardır. Ancak tersi durum söz konusu değildir. 
Tablo 3: AB ile Türkiye'nin Ortak Şekilde ve Sadece AB'nin Serbest Ticaret Anlaşması İmzaladığı Ülkeler Listesi

\begin{tabular}{|c|c|}
\hline EFTA (Norveç, İsviçre, Lihteştayn) & Kanada \\
\hline İsrail & $\begin{array}{l}\text { SADC } \\
\text { Southern African Development Community Angola, Mozambique, Tanzania as } \\
\text { well as Botswana, Lesotho, Namibia, Swaziland }\end{array}$ \\
\hline Makedonya & Colombia and Peru - Accession of Ecuador \\
\hline Bosna ve Hersek & Ukrayna \\
\hline Filistin & Orta Amerika \\
\hline Tunus & Eastern Africa States Interim EPA \\
\hline Fas & Papua New Guinea / Fiji \\
\hline *Suriye & San Marino \\
\hline Mısır & Kamerun \\
\hline Arnavutluk & $\begin{array}{l}\text { CARIFORUM States EPA } \\
\text { The Caribbean Community + Dominic Republican }\end{array}$ \\
\hline Gürcistan & Cezayir \\
\hline Karadağ & Güney Afrika \\
\hline Sırbistan & Meksika \\
\hline Şili & Andora \\
\hline Ürdün & Suriye* \\
\hline Güney Kore & Overseas Countries and Territories (OCT) \\
\hline Moldova & \\
\hline Faroe Adaları & \\
\hline Moritus & \\
\hline Malezya & \\
\hline Singapur & \\
\hline
\end{tabular}

Kaynak: http://rtais.wto.org/Ul/PublicAllRTAList.aspx

*: Türkiye'nin Suriye ile serbest ticaret anlaşması karşılıklı olarak durdurulmuştur. Ancak AB ile Suriye arasındaki anlaşma devam etmektedir. Dolayısıyla Türkiye'nin GB dolayısıyla Suriye ile olan durumu karışıklık arz etmektedir.

Tablo 3'de ise Türkiye'nin serbest ticaret anlaşması yapmadığı ancak AB ile gerçekleştirdiğimiz Gümrük Birliği nedeniyle $A B^{\prime}$ nin yaptığı anlaşma gereği zorunlu olarak ve tek tarafıı (Türkiye aleyhine) gümrük engellerini kaldırmamızın gerektiği ülkeler (ikinci sütun) görülmektedir.

1996 yııında Gümrük Birliği anlaşması imzalandıktan sonra da serbest ticaret anlaşmalarının yapılması yeni bir boyut kazanmıştır. Bu çerçevede Türkiye sadece Gümrük Birliği dolayısıyla AB'nin anlaşma imzaladığı ülkelerle karşııklı fayda esasına dayalı anlaşmalar yapmaktadır (T.C. Ekonomi Bakanlığı, Serbest Ticaret Anlaşmaları Portalı, http://www.ekonomi.gov.tr/portal/content/conn/UCM/path/Contribution\%20Folders/web). 


\section{Grafik 1: Türkiye’nin Serbest Ticaret Anlaşmaları Yoluyla Dış Ticaret Durumu (2007-2017)}

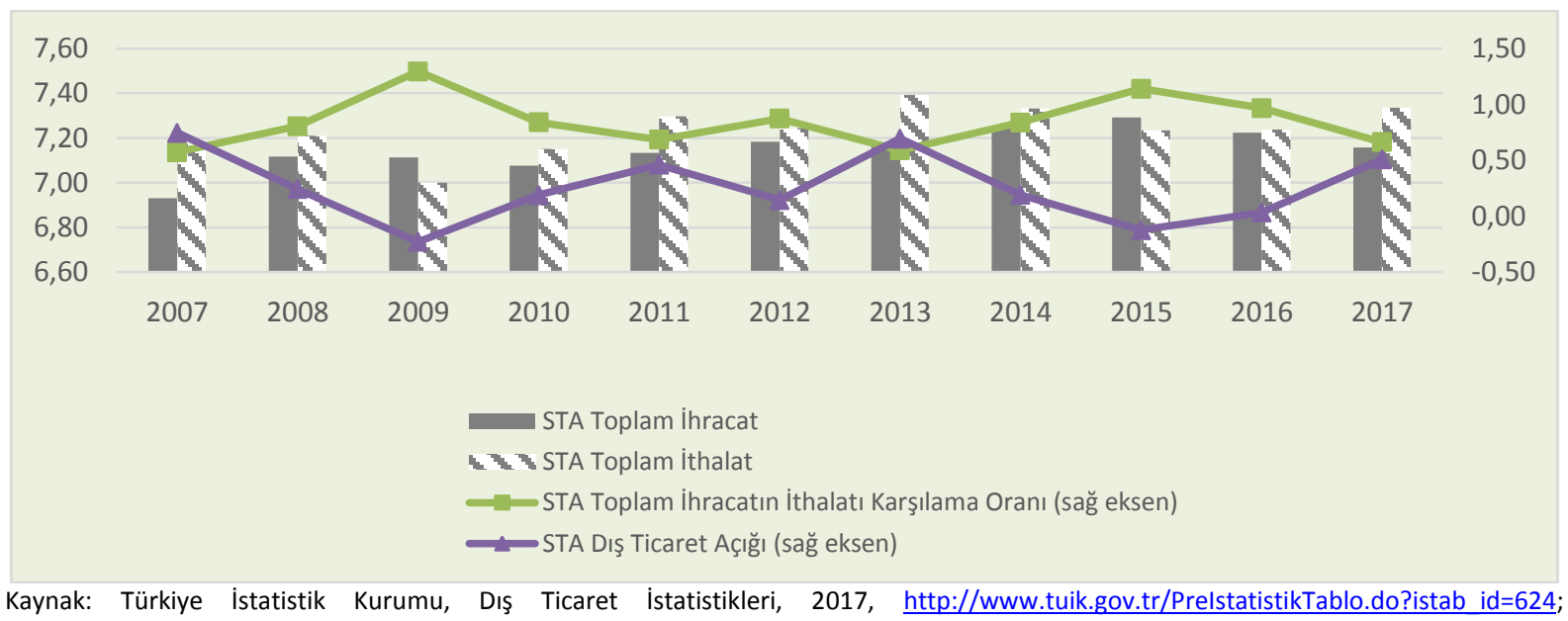

http://www.tuik.gov.tr/PrelstatistikTablo.do?istab_id=625

Grafik 1'de serbest ticaret anlaşmaları yoluyla gerçekleştirilen ihracat ve ithalat işlemleri, ihracatın ithalatı karşılama oranı ve açık durumu görülmektedir. 2007 ve 2017 yılları arasında içinde 2017 yılının da olduğu 8 sene ithalat ağırlığı görülmektedir. Dolayısıyla beklenir şekilde bu yıllardan çoğunda karşılama oranı düşmüş ve açık artmıştır. Bu ham sonuçlar iki şekilde ince ayarla yorumlanabilir. Bunlardan ilki dış ticaret açıklarının sadece nihai ürün ithalatından kaynaklanmadı̆̆ıdır. Bu konuda daha ayrıntılı bir gözlemle eğer hammadde ve aramalı ithalatı nedeniyle artış yaşanıyor ve uzun vadede bu durum ihracat ile sonuçlanıyorsa döviz kaybı karşılaştırması yapılması gerekir. İkinci yorum ise ihracatın artış hızının ithalatı aştığı durumlarda ithalat rakamsal olarak büyük olsa dahi karşılama oranının yükseldiğinin ve açığın artış hızının yavaşladığının görüldüğüdür. Söz konusu durumun yaşandığı 2008, 2012 ve 2014 yılları örnek olarak verilebilir.

\subsubsection{Türkiye'deki Serbest Ticaret Bölgeleri}

$A B$ mevzuatında, gümrük bölgesinin bir bölümünün serbest bölge olarak belirlenmesi yetkisi gümrük birliği içinde olunan ülkenin kendisine bırakılmaktadır (COUNCIL REGULATION (EEC) No 2913/92 of 12 October 1992; Chapter 3, Section 1, Article 166). Türkiye'de serbest bölgelerin oluşturulmasına ilişkin yasal düzenleme 3218 sayılı Kanun ile belirlenmiştir. Bu kanuna göre serbest bölgeler, Türkiye dışında bir ülke olarak kabul edilmektedir. İhracat ve ithalat işlemleri açısından; serbest bölgenin tanımlandığı ülkeden serbest bölgeye mal girişi ve serbest bölgelerden dış ülkelere mal çıkışı ihracat, serbest bölgeden kurulduğu ülkeye mal girişi ve dış ülkelerden serbest bölgeye mal girişleri ise ithalat işlemi olarak belirlenmiştir (Güngör, 2015).

Tablo 4: Türkiye Serbest Bölgeler Dış Ticaret Durumu

\begin{tabular}{|c|c|c|c|c|}
\hline & \multicolumn{2}{|c|}{ İHRACAT } & \multicolumn{2}{|r|}{ ITHALAT } \\
\hline & $\begin{array}{l}\text { Serbest } \\
\text { Bölgelerden } \\
\text { Yurt Dışına }\end{array}$ & $\begin{array}{c}\text { Yurt İçinden } \\
\text { Serbest } \\
\text { Bölgelere }\end{array}$ & $\begin{array}{c}\text { Yurt Dışından } \\
\text { Serbest Bölgelere }\end{array}$ & Serbest Bölgelerden Yurt İçine \\
\hline Ocak-Aralık 2014 & 7957871 & 2732526 & 7058603 & 4683242 \\
\hline Ocak-Aralık 2015 & 7493675 & 2205295 & 6549732 & 4011960 \\
\hline 2014-2015 Değişim & -5.83 & -19.29 & -7.21 & -14.33 \\
\hline Ihracat / İthalat 2014 & & & 0.91 & \\
\hline İhracat / İthalat 2015 & & & 0.92 & \\
\hline
\end{tabular}

Kaynak: T.C. Ekonomi Bakanlığı, Serbest Bölgeler Portalı Verileri,

https://www.ekonomi.gov.tr/portal/content/conn/UCM/uuid/dDocName:EK-070995

Tablo 4'de 2014- 2015 yıllarında Türkiye'deki serbest bölgelerin mal giriş ve çıkış işlemleri görülmektedir. İhracatın ithalatı karşılama oranı her iki yılda da çok yüksek olmasına rağmen her iki yılda ithalat faaliyetlerinin miktar olarak yüksekliğinin gözlendiğini ve bunun döviz kaybı yarattığı ifade edilebilir. Serbest bölgelerin ithalat işlemelerinde temel saiklerin; sağlanan vergi avantajları ve depolama faaliyeti olduğu katma değer yaratılmadığı ifade edilmektedir (Serbest Bölgeler Uzmanlık Tezi, 
2003: 147). Serbest bölgelerin daha çok ithalatı kolaylaştırarak döviz kaybına neden olduğu konusunda eleştirilerin olduğu da belirtilmektedir (Öztürk, 2013: 79).

\subsubsection{Gümrük Birliği Anlaşması}

Türkiye, AB ile 1995 yılında Ortaklık Konseyi toplantısında alınan karar çerçevesinde Gümrük Birliği'ne girmiş, 1/95 Sayılı Ortaklık Konseyi kararının 10. Maddesi uyarınca; $A B$ ile dış ticaret rejimini uyumlu hale getirmeyi ve üçüncü ülkelerle gerçekleştirilecek dış ticaret faaliyetlerinde kendi gümrük tarifesini Topluluğun Ortak Gümrük Tarifesini dikkate alarak uygulayacağını taahhüt etmiştir (Güllü, 2014: 99).

Söz konusu taahhüt ile üçüncü ülkelere ihracat faaliyeti hem $A B$ hem de üçüncü ülkelere göre malların Türkiye'de daha ucuza üretilebilmesine, üçüncü ülkelerden ithalat faaliyeti ise ithal edilecek malların üçüncü ülkelerde $A B$ mallarından daha ucuz olmasına bağlanmıştır (Aktaş ve Güven, 2003: 71). Bu aşamadan sonra Ortaklık Konseyi kararının 16.maddesi gereği Türkiye, AB'nin çeşitli ülkelerle yaptığı Serbest Ticaret Anlaşmalarına benzer anlaşmalar (EFTA, İsrail, Makedonya, Hırvatistan, Bosna Hersek, Filistin, Tunus, Fas, Suriye, Mısır, Arnavutluk, Gürcistan, Karadağ, Sırbistan, Şili, Ürdün, Lübnan) yapmıştır (Güllü, 2014: 99).

Türkiye'nin Gümrük Birliği anlaşması ile dış ticaret faaliyetleri açısından avantaj ve dezavantajlarına ilişkin bulgular Tablo 5 'de kısaca belirtilmiştir.

Tablo 5: Gümrük Birliğine Girişin Türk Dış Ticaret Yapısına Etkisini İnceleyen Çalışmalar

\begin{tabular}{|c|c|}
\hline YAPILAN ÇALIŞMALAR & BULGULAR \\
\hline KRUEGER, O. A. etc. (1996) & $\begin{array}{l}\text { Türkiye'nin Gümrük Birliğine dâhil olması ile yaşanacak cari işlemler } \\
\text { dengesi sorunları bulgulanmıştır. }\end{array}$ \\
\hline DPT-a-, (1996) & $\begin{array}{l}\text { Gümrük vergilerinin kaldııılması ve ortak gümrük tarifesi uygulaması } \\
\text { ile ithalatın önemli ölçüde arttığı belirtilmiştir. }\end{array}$ \\
\hline HARRISON, G. W. etc. (1997) & $\begin{array}{l}\text { Gümrük Birliğine giriş ile Türkiye'nin GSYH'sının \%1 ila \%1.5 kadarlık } \\
\text { bir kazancının olacağı, gümrük vergisi kaybının ise GSYH'sının \%1.4'ü } \\
\text { kadar olacağı ifade edilmiştir. }\end{array}$ \\
\hline MERCENIER, J. ve YELDAN, E. (1997) & $\begin{array}{l}\text { Tam üyelik olmaksızın yani kısmi ticaret serbestisi ile Gümrük } \\
\text { Birliğine girişin Türkiye'de hanehalkı yoksullaşmasına yol açacağı } \\
\text { bulgulanmıştır. }\end{array}$ \\
\hline MORGIL, O. (2000) & $\begin{array}{l}\text { Gümrük Birliğine girişin ticaret saptırıcı etkisi olmasa da ticaret } \\
\text { yaratıcı etkisi sınırlı miktarda olmuştur. }\end{array}$ \\
\hline TOGAN, S. (2000) & $\begin{array}{l}\text { Gümrük Birliğine girişin Türkiye açından } A B^{\prime} \text { ye yapılan ihracatta } \\
\text { önemli bir artış yaratmadığı, ithalatta da üçüncü ülkelerden yapılana } \\
\text { göre } A B^{\prime} \text { 'den daha fazla ithalat yapıldığı bulgulanmıştır. }\end{array}$ \\
\hline DPT -b-, (2000) & $\begin{array}{l}\text { Gümrük Birliğine giriş ile } A B \text { ve üçüncü ülkelerden yapılan ithalatın } \\
\text { arttığı ifade edilmiştir. }\end{array}$ \\
\hline UYAR, S. (2001) & $\begin{array}{l}\text { Gümrük Birliği ile ithalatın ihracattan daha hızlı artması sonucu, } \\
\text { ticaret yaratıcı etkinin Türkiye aleyhine geliştiği, imalat sanayinde } \\
\text { ithalat miktarının ihracat miktarından daha büyük olmasının da söz } \\
\text { konusu ürünleri birlik içinde ucuza üreten ülkelerin üretim ve } \\
\text { gelirlerini artı̆̆ı, gelir dağılımının Türkiye'nin aleyhine geliştiği } \\
\text { bulgulanmıştır. }\end{array}$ \\
\hline MANISALI, E. (2001) & $\begin{array}{l}A B \text { çıkışlı imalat sanayi mallarının gümrük olmadan ithal edilmesi ve } \\
\text { üçüncü ülkelere karşı } A B \text { tercihlerine bağlı olarak gümrük uygulaması } \\
\text { zorunluluğunun Türkiye dış ticaretinde sapmaya yol açtığı ifade } \\
\text { edilmiştir. }\end{array}$ \\
\hline ÖĞÜT, K. (2003) & $\begin{array}{l}\text { Gümrük Birliğinin Türkiye'nin dış ticaret açığında yapısal bir değişime } \\
\text { yol açtığı bulgulanmışır. }\end{array}$ \\
\hline AKTAŞ, C. ve GÜVEN, D. (2003) & $\begin{array}{l}\text { Gümrük Birliğine girdikten sonra; } \\
\text { - Brüt döviz rezervinde } 1 \text { birimlik değişikliğin ithalat miktar } \\
\text { endeksinde öncesine göre daha büyük bir artışa, } \\
\text {-ìnracat miktar endeksindeki } 1 \text { birim değişikliğin ithalat miktar } \\
\text { indeksini öncesine göre daha büyük bir artışa, } \\
\text {-Toplam Sanayi Üretim endeksindeki } 1 \text { birimlik değişikliğin ithalat } \\
\text { miktar endeksinde öncesine göre daha büyük bir artışa yol açtığı } \\
\text { saptanmıştır. }\end{array}$ \\
\hline
\end{tabular}




\begin{tabular}{|c|c|}
\hline ÇAK, D. ve ÇAK, M. (2007) & $\begin{array}{l}\text { Gümrük Birliğine girişin üçüncü ülkelerden yapılan ithalatı artırdığına } \\
\text { buna karşılık ihracatın yıllık artış hızı üzerinde olumlu bir etkinin } \\
\text { ortaya çıkmadığı bulgulanmıştır. }\end{array}$ \\
\hline GÜNDÜZ, O. ve ESENGÜL, K. (2007) & $\begin{array}{l}\text { Gümrük Birliğine girişin ihracata göre ithalat değerlerinde daha çok } \\
\text { artışa yol açtığı tespit edilmiştir. }\end{array}$ \\
\hline NEYAPTI, B. vd. (2007) & $\begin{array}{l}\text { Gümrük Birliğine girişin Türkiye'nin dış ticaret hacmini genişletme } \\
\text { anlamında olumlu bir katkısının olduğu ancak Birlik süreci sonrasında } \\
\text { ihracatın özellikle kur değerindeki sapmadan çok etkilendiği } \\
\text { bulgulanmıştır. }\end{array}$ \\
\hline KÖSEKAHYAOĞLU, L. (2007) & $\begin{array}{l}\text { Gümrük Birliği sonrasında ithalatın ürün yapısında az ancak ihracatın } \\
\text { yapısında çok önemli değişimler olduğu gözlenmiştir. }\end{array}$ \\
\hline KIZILTAN, A. Vd. (2008) & $\begin{array}{l}\text { Gümrük Birliğine girişle Türkiye } 10 \text { yıllık süreçte dış ticareti artırıcı } \\
\text { etkiler ortaya çıkardığı bulgulanmıştır. }\end{array}$ \\
\hline GÖKDEMIR, L. ve KARAMAN, E. (2008) & $\begin{array}{l}\text { Birliğin Türkiye net refahı üzerindeki etkisinin kısıtlı olduğu sonucuna } \\
\text { varılmıştır. }\end{array}$ \\
\hline TEMiz, D. (2009) & $\begin{array}{l}\text { Gümrük Birliğine girişin ardından dıs ticaret hacminde ithalattan } \\
\text { kaynaklanan artış olup ancak net ihracatta azalma bulgulanmıştır. }\end{array}$ \\
\hline SEYMEN, D. (2009) & $\begin{array}{l}\text { Gümrük Birliğine girişin dış ticarette ülke yoğunluğunu etkileme } \\
\text { gücünün sınırlı kaldığı ifade edilmiştir. }\end{array}$ \\
\hline ALTAY, H. vd. (2009) & $\begin{array}{l}\text { AB çerçevesinde yüksek katma değerli sanayiler açısından pazar } \\
\text { avantajının sağlanamadığı ve Gümrük Birliği açısından beklenen } \\
\text { sonuçların alınamadığı bulgulanmıştır. }\end{array}$ \\
\hline ÇOLPAN NART, E. (2010) & $\begin{array}{l}\text { Gümrük Birliğine girişin ticaret yaratıcı etkiler meydana getirdiği } \\
\text { belirtilmiştir. }\end{array}$ \\
\hline KALAYCI, C. ve ARTAN, S. (2010) & $\begin{array}{l}\text { Gümrük Birliğinin } A B \text { ülkeleri birlik içi ticaretini ve Türkiye ile } A B \\
\text { arasındaki ihracatı artırmasına rağmen, Türkiye ihracat artışının } \\
\text { diğerinden daha az olduğu sonucuna varılmıştır. }\end{array}$ \\
\hline DOĞAN, S. ve KAYA, S. (2011) & $\begin{array}{l}\text { Gümrük Birliği sonrasında ülke bazlı yoğunlaşmada değişikliğin } \\
\text { olmadığı, ihracatta ürün bazına yapısal bir değişim gözlenmesine } \\
\text { karşın ithalatta } A B \text { bağımlıı̆ın azalmadığı bulgulanmıştır. }\end{array}$ \\
\hline YERGIN, H. vd. (2014) & $\begin{array}{l}\text { Katma değere sahip önemli bazı ürün gruplarında dış ticaret } \\
\text { hacminin ithalat yönlü olmasından kaynaklı dış açığın ortaya çıktığı } \\
\text { bulgulanmıştır. }\end{array}$ \\
\hline MESUT, D. 2015 & $\begin{array}{l}\text { Gümrük Birliğine giriş sonrasında verilerin daha çok } A B \text { lehine ticaret } \\
\text { yaratıcı ve saptırıcı etkileri işaret ettiği belirtilmiştir. Zaman içinde } \\
\text { ihracat artışı gözlense de ithalat artışında önemli gelişmelerin olduğu } \\
\text { ifade edilmiştir. }\end{array}$ \\
\hline KARAGÖZ, 2017 & $\begin{array}{l}\text { Gümrük Birliği Anlaşması sonrası Türkiye'nin } A B^{\prime} y e \text { ihracat } \\
\text { oranındaki artış ortalamanın çok daha fazlası şeklinde } \\
\text { gerçekleşmiştir. İhracatın fiyata duyarlıığındaki artış ile ilgili güçlü } \\
\text { kanıt bulunamamıştır. Ayrıca } A B \text { ülkelerinden Türkiye'ye yapılan } \\
\text { ithalatın da fiyat duyarlılığında bir değişiklik gözlenmemiştir }\end{array}$ \\
\hline AKÇA, BAL VE ÇAĞLAYAN, 2017 & $\begin{array}{l}\text { Yapılan çalışma sonucunda Gümrük Birliğinin ticaret yaratıcı ancak } \\
\text { sınırlı bir etkiye sahip olduğu bulgulanmış, Türkiye toplam ihracat } \\
\text { pazar payına yönelik incelemede Gümrük Birliği sonrası } A B^{\prime} \text { ye yönelik } \\
\text { ihracat payının düştüğü diğer ülke piyasalarında ise arttığı dolayısıyla } \\
\text { Birliğin ticaret saptırıcı etkisinin olmadığı tespit edilmiştir. Gümrük } \\
\text { Birliği pozitif etkiye sahip olsa da bazı mallar itibariyle Türkiye } \\
\text { açısından halen tarife dezavantajının söz konusu olduğu bundan } \\
\text { dolayı bu mallara yönelik tarife engellerinin oluşturulması gereği } \\
\text { ifade edilmektedir }\end{array}$ \\
\hline
\end{tabular}

Kaynak: [(Kuşat, 2015), (Öğüt, 2003), (Altay vd., 2009), (Yergin vd., 2014), (Doğan, 2015), (Öğüt, 2003), (Aktaş ve Güven, 2003), (Mercenier ve Yeldan, 1997), (Harrison etc., 1997), (Neyaptı etc., 2007)]'den bulgular ile (Arslan ve Çaşkurlu, 2016, s. 660 - 662); Karagöz, 2017: 37; Akça, Bal ve Çağlayan, 2017, 15 
Tablo 5'de belirtilen bulgulara dayanılarak Türkiye'nin dış ticaret yapısına ilişkin sonuçlar şu şekilde özetlenmiştir (Arslan ve Çaşkurlu, 2016: 663):

- Gümrük Birliği yeni pazarlara açılma ve dış ticarette çeşitli fırsatların sağlanması açısından avantajlı olmuş ve dolayısıyla Türkiye dış ticaretinin bu durumdan belli ölçülerde olumlu etkilenmiştir.

- Ancak Gümrük Birliği sonrasına dış ticaretteki hacim artışı, genellikle "ithalat" şeklinde gerçekleşmiş ve dolayısıyla daha çok $A B$ lehine olmuştur.

- Dış ticaret hacmine ilişkin kazançların ve gümrük vergisi kayıplarının karşılaştırılması gereğinin ortaya çıkmışır.

- Dış ticaret yapısında Birliğe giriş sonrasında ortaya çıkan değişiklikler, dış ticaret faaliyetlerinin kur oynaklığına duyarlıı̆̆ını daha fazla artırmıştır.

- Tam üyelik olmaksızın Gümrük Birliğine giriş, dış ticaret kazançlarından ziyade refah kayıplarına yol açabilmektedir.

- Dış ticaret ürün çeşitliliği konusunda, Birliğe giriş sonrasında Türkiye açısından katma değeri düşük mal ticaretinin yapılması durumu ortaya çıkmıştır.

\subsubsection{Türkiye’ye Yönelik Doğrudan Yabancı Sermaye Yatırımları}

Doğrudan yabancı yatırım Karluk 1998'de; girişim, teknoloji risk taşıma ve organizasyon aktarımının içine dâhil olduğu bir sermaye transferi faaliyeti olarak tanımlanmaktadır (Karluk, 1998: 134). Sarısoy ve Koç 2012'de de kalıı fayda sağlamaya yönelik sermaye ve/veya iş faaliyeti transferi olarak ifade edilmiştir (Sarısoy ve Koç, 2012: 189).

Doğrudan yabancı yatırımlar yoluyla ithalat ve ihracat akımlarının etkilenmesi söz konusu olmaktadır. Sarısoy ve Koç 2012 'de yapılan ampirik bir çalışmada; doğrudan yabancı yatırımların yatırımın yapıldığı çalışmada ele alınan ve içinde Türkiye'nin de olduğu ülkelerde ithalatı artırdığına ilişkin bir sonuç bulunmuştur (Sarısoy ve Koç, 2012: 204). Doğrudan yabancı yatırım ve serbest bölgeler arasındaki ilişkinin sınandığı bir başka çalışmada ise serbest bölgelerin Türkiye'de doğrudan yabancı yatırım çekmek açısından çok etkin olmadığına ilişkin bulgulara ulaşılmıştır (Düzenli, 2003: 130).

\section{Grafik 2: Doğrudan Yabancı Yatııım Alınan (Yükümlülük) ve Yapılan (Varlık) Farkı}

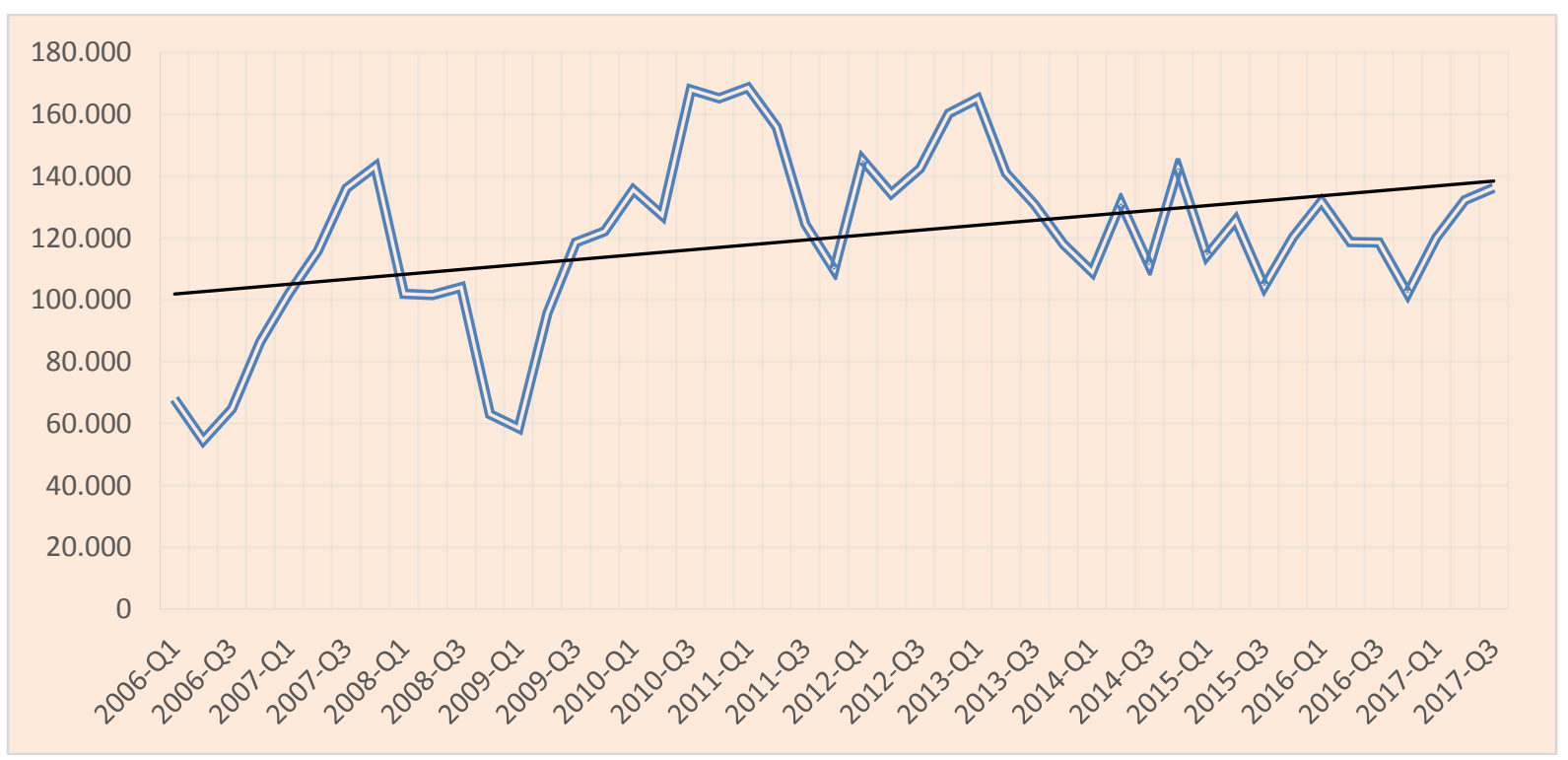

Kaynak: Merkez Bankası, Elektronik Veri Destek Sistemi, https://evds2.tcmb.gov.tr/index.php?/evds/serieMarket/collapse 18/5003/

Grafik 2'de doğrudan yabancı yatırımların gelişimi; ülke yatırım pozisyonu dahilinde varlıklar içindeki yapılan doğrudan yabancı yatırımlar ile yükümlülükler içindeki alınan doğrudan yabancı yatırımlar arasındaki farkın ortaya konması şeklinde incelenmiştir. Çeyrek dönemler itibariyle ele alınan incelemede 2013 birinci çeyrekten itibaren düşen fark, 2014 ikinci ve dördüncü çeyrek dışında eğim çizgisinin üzerine çıkmamış ve düşüş eğilimini korumuştur. Ancak 2016 dördüncü çeyreği itibariyle tekrar artış eğilimine girmiş ve yükselmeye devam etmektedir. Bu anlamda söz konusu yatırımların kısa vadede döviz kaybı ektisi görülmektedir. Ancak uzun vadeli etkisinin hangi yönde olacağının araştırılması gerekir. 


\section{VERILER VE METHODOLOJi}

\subsection{Türkiye Dış Ticaretinin Genel Yapısı -Güçlü ve Kırılgan Yönler}

Türk dış ticaret yapısına belli açılardan değinip, mevcut durumun kırılganlıkları ve güçlü yanlarının olası anlaşmanın olumluolumsuz yanlarını artırıcı ve/veya azaltıcı unsurlarını ele almak gerekmektedir.

\subsubsection{Dış Ticaret Genel Düzey ve İçerik Değerlendirmesi}

Dış ticaretin genel gelişimi ve söz konusu gelişimin içeriğinin ele alınması, dış ticareti etkileyecek unsurların hangi yönlerden avantaj ve dezavantaj yaratabileceğinin analizi açısından gerekli olmaktadır.

\section{Grafik 3: Mevsim ve Takvim Etkisinden Arındırılmış Dış Ticaret Durumu}

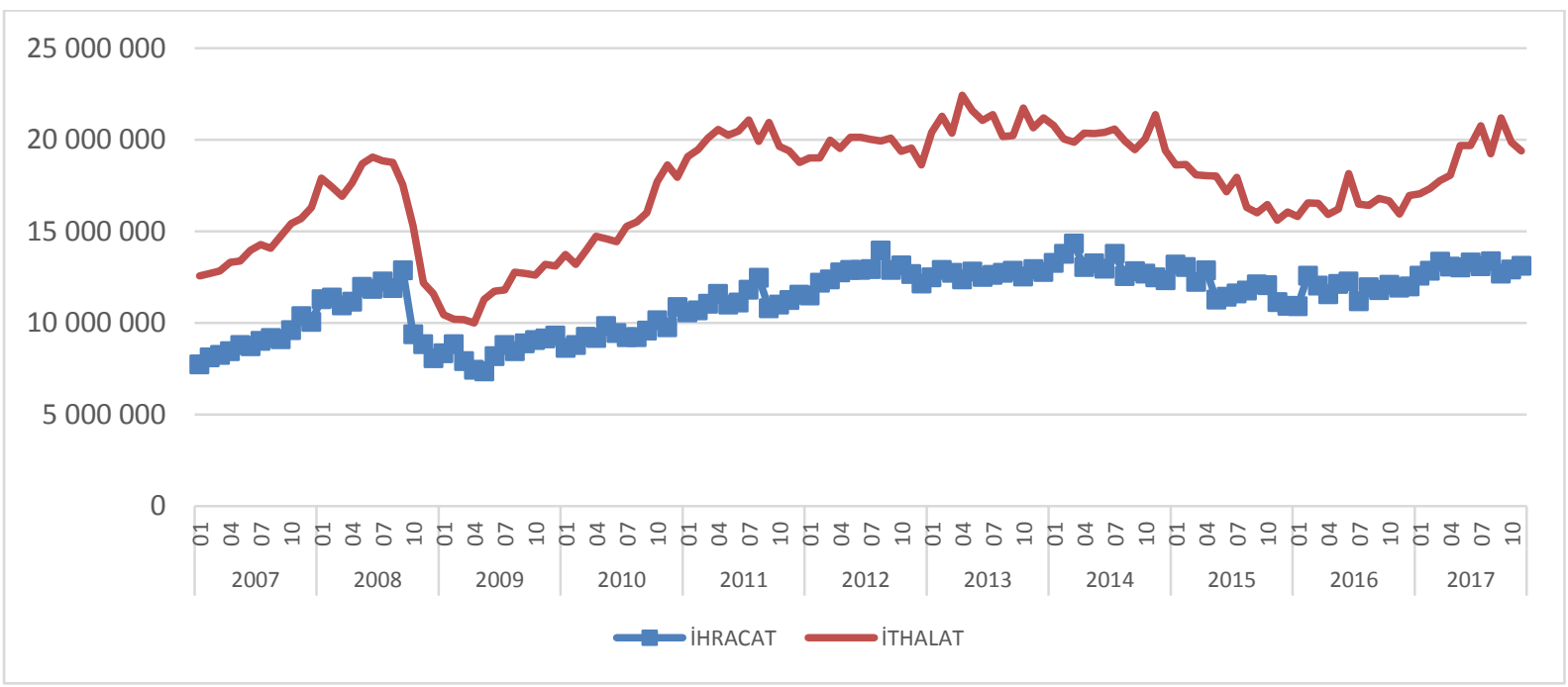

Kaynak: Türkiye İstatistik Kurumu, Dış Ticaret İstatistikleri, 2017, http://www.tuik.gov.tr/PrelstatistikTablo.do?istab_id=1343

Türkiye açısından 2007 - 2017 yılları arasında mevsim ve takvim etkilerinden arındırılmış dış ticaret durumuna bakıldığında gelişimin ithalat lehine olduğu görülmektedir. Ancak ithalat ağırlığı olsa da içeriğine bakmak gerekmektedir.

\section{Grafik 4: Ekonomik Sınıflandırmaya Göre Dış Ticaret - Net Ticaret (2011-2017)}

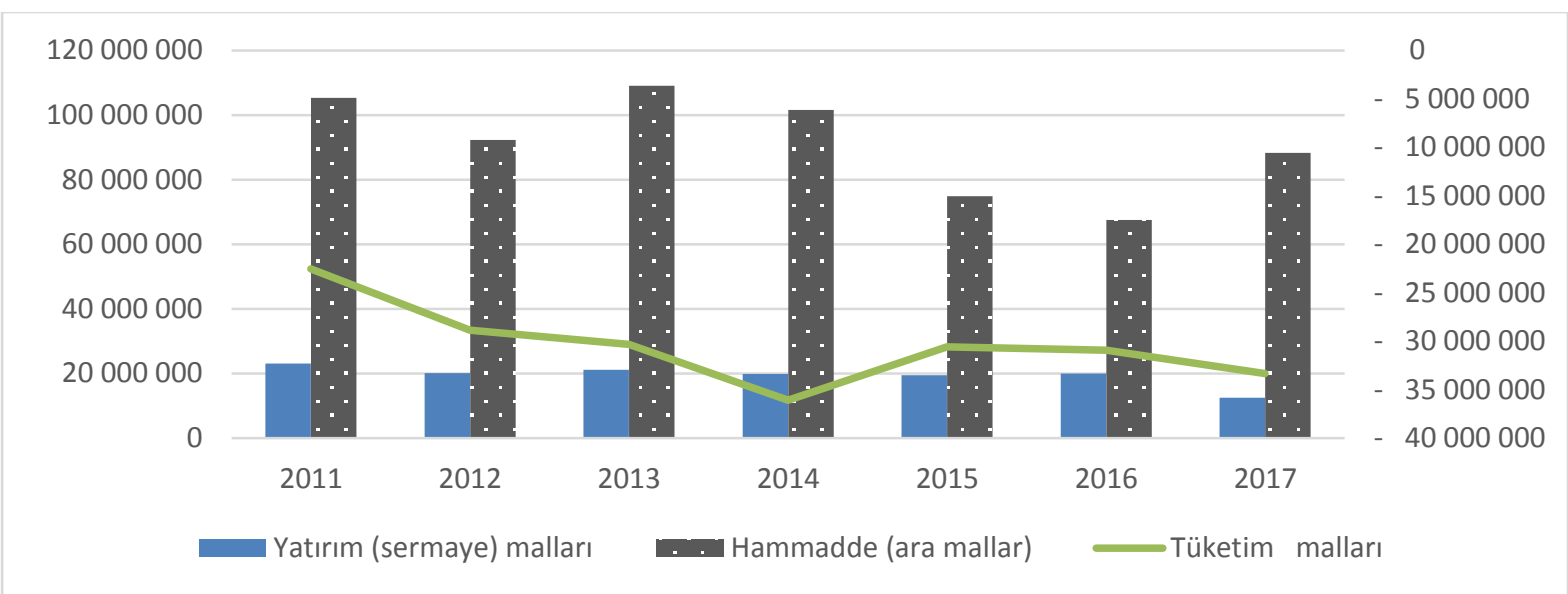

Kaynak: Türkiye Istatistik Kurumu, Dış Ticaret İstatistikleri, 2017, http://www.tuik.gov.tr/PrelstatistikTablo.do?istab_id=630; http://www.tuik.gov.tr/PrelstatistikTablo.do?istab id=629

Grafik 4'de 2011 ve 2017 yılları arasında net dış ticaret ekonomik sınıflandırmaya göre incelenmektedir. Grafikteki gelişime bakıldığında en çok hammadde (aramaları) ithalatının yapıldığı ve ikinci sırayı da yatırım mallarının aldığı görülmektedir. Tüketim malları itibariyle net dış ticaret sürekli ihracat lehinedir (sağ eksen). Tüketim mallarına ilişkin 2011 yılındaki ithalat artışına bağlı olarak yüksek gerçekleşen seri, 2017 yılı dahil olmak üzere düşüş eğilimindedir. Ara malı ve yatırım 
mallarındaki net dış ticaret, doğal kaynak açısından yeterli zenginliğin olmamasından kaynaklanmaktadır (Hasanov, 2014: 18). Bu durum Türkiye'de üretimin ve ihracatın, ithal bağımlılı̆ının bir işareti olmaktadır. İthal bağımlılığının yarattığı bir diğer sorun da geleneksel dış ticaret teorisinde, ülke kur oynaklığının yerli para değer kaybına neden olduğu durumlarda ülkeye ihracat avantajı sağladığı şeklindeki geleneksel savın geçersizliğidir. İthal bağımlılığı ne kadar yüksekse, para değer düşüklüğünün ihracat hacmi üzerindeki etkisinin o kadar düşük olduğu çeşitli çalışmalarda ifade edilmektedir (Ahmed et.al., 2015:17; Kılıç ve Yıldırım, 2015: 198).

\subsubsection{Dış Ticarette Katma Değer Oluşumu ve Etkileri}

İhracatın parasal miktarı ya da hangi ülkelere yapıldığından ziyade söz konusu faaliyette ne kadar katma değerin yaratıldığı önem kazanmaktadır. Johnson 2014'de katma değer ticareti adı verilen söz konusu durumun toplam ticaretle farklı şekilde yorumlanması gereği ifade edilmiştir (Johnson, 2014: 140).

Miroudot ve Yamano, 2013'de üretimin küreselleşmesine bağlı olarak farklı ekonomik ortamlarda herhangi bir ürüne çoklu katma değer eklenebileceği ifade edilmektedir (Miroudot ve Yamano, 2013: 18). Katma değer zincirlerinde, ülkelerin ticarete ve yabancı sermayeye açıklıkları ile diğer stratejik belirlemelerinin önem taşıdığı belirtilmiştir (Greffi ve Luo, 2014: 9). Ticarette ürün kompozisyonu ve bununla ilişkili faktör yoğunluğu konusu dikkate alındığında, katma değer açısından gelişmekte olan ülkelerin ihracat ürün çeşitliliğinde uzmanlaşma yoğun sektörlere doğru bir çeşitlilik artışının olması gerektiği ifade edilmektedir (Fontagne, Foure, Knack, 2017, 57). Erkan ve Yıldırımcı (2015)'de, Türkiye açısından bakıldığında üretim ve ihracatta emek yoğun yapının, katma değer yaratımını engellediği ve uluslararası pazardaki güç yapısını olumsuz etkilediği belirtilmektedir (Erkan ve Yıldırımcı, 2015: 533). Dış ticaretin gelişimi ve bu yolla refah artışı sağlanması bağlamında Türkiye'de enerji ithal bağımlılığının ve ihracatta katma değeri düşük ürünlerin üstünlüğünün değiştirilmesi gereği ifade edilmektedir (Tunalı ve Aytekin, 2017: 113). Bu anlamda yapılan bir çalışmada üretim ve yatırımların ithal girdi ve sermaye malı bağımlılığının olumsuzluğuna işaret edilmiştir (Bayar 2017, s.173).

Buradan hareketle Türkiye ihracatında katma değer oluşumu diğer ülke örnekleriyle birlikte Grafik 5 ve 6 'da verilmiştir. Karşılaştırma verileri OECD’nin ilgili veri setinden alınarak incelenmektedir. Son yıl resmi verilerde 2011 yılıdır.

Grafik 5: İhracatta Yerli ve Yabancı Katma Değer Payı (2001 - 2011 ort., \%)

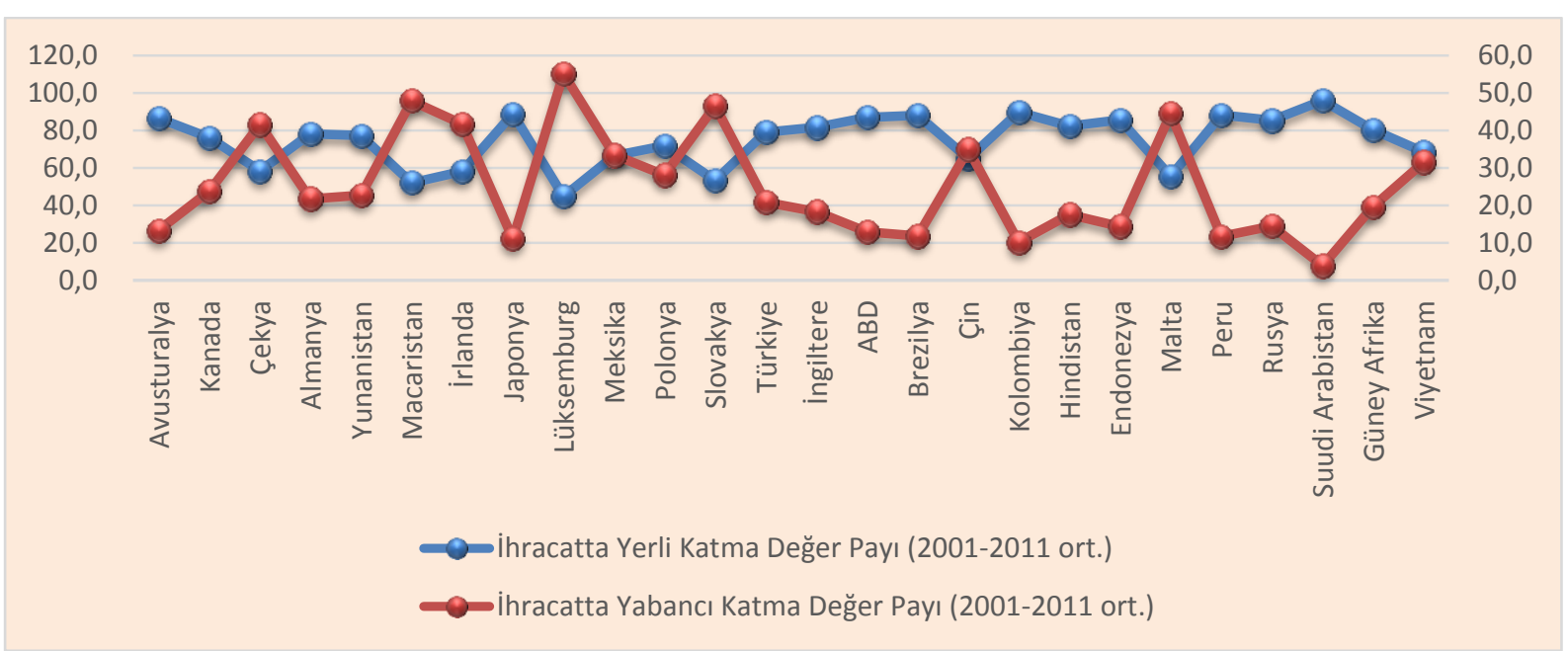

Kaynak: OECD-WTO: Statistics on Trade in Value Added, http://www.oecd-ilibrary.org/trade/data/oecd-wto-statistics-on-trade-in-valueadded_tiva-data-en.

Grafik 5'de ihracatta yerli ve yabancı katma değer payları ele alınan yıllar itibariyle ortalama olarak gösterilmiştir. Genel olarak bakıldığında ülkelerin yerli katma değer payları yabancı paya göre daha yüksektir. İstisna teşkil eden Lüksemburg da yabancı katma değeri yüksektir. Malta, Macaristan ve Slovakya'da da değerler birbirine çok yakındır. Katma değer incelemesinde temel olan rakamsal gelişimin yanı sıra hangi ürünlerin ihraç edildiğinin sınanmasıdır. Örneğin Suudi Arabistan'da yerli katma değer çok yüksektir. Ancak petrol ürünleri ihracatı söz konusu olduğundan beklenir bir durumdur. 


\section{Grafik 6: İhracatta Yerli ve Yabancı Katma Değer Payı (2001 - 2011 \% değişme)}

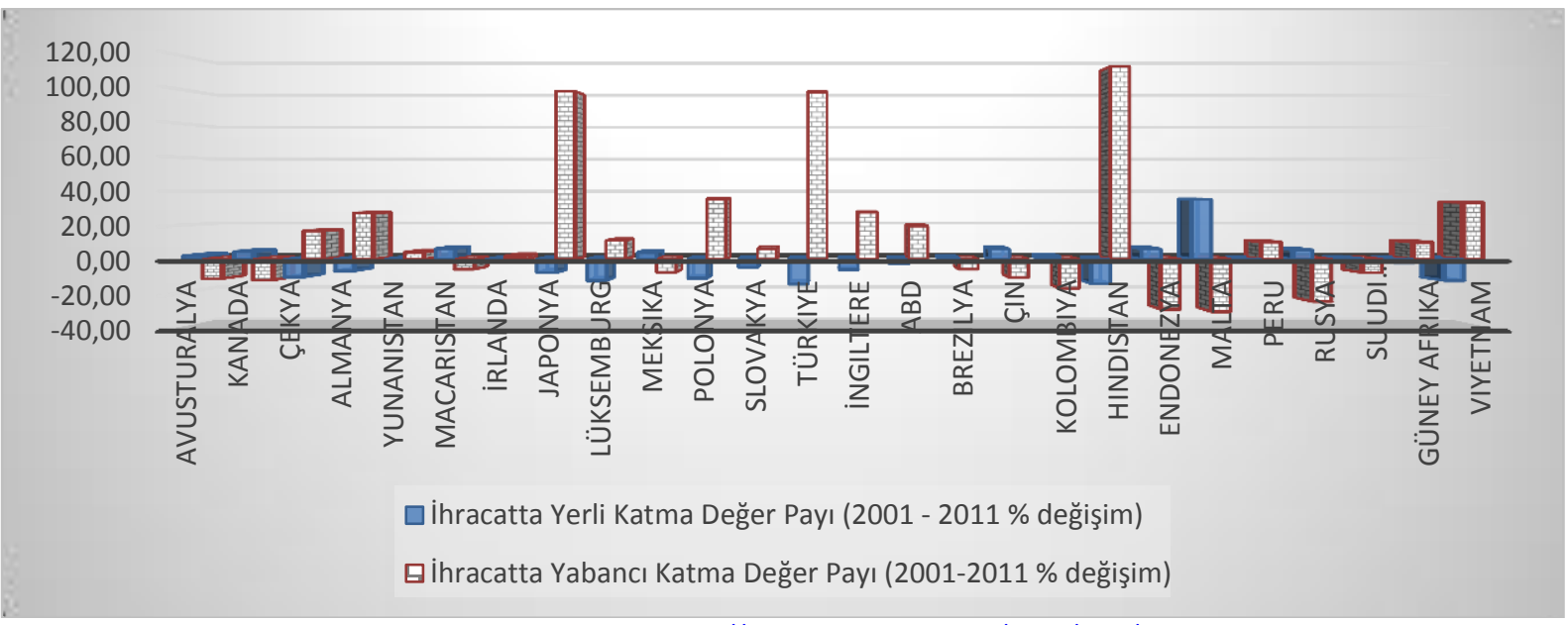

Kaynak: OECD-WTO: Statistics On Trade In Value Added, http://www.oecd-ilibrary.org/trade/data/oecd-wto-statistics-on-trade-in-valueadded tiva-data-en

Grafik 6'da ise ihracattaki katma değer payı ele alınan yıllar arasındaki değişim durumu göz önüne alınarak incelenmiştir. Burada durum Avusturalya, Kanada, Macaristan, Brezilya, Çin, Kolombiya, Endonezya, Malta, Rusya ve Suudi Arabistan için ihracatta yerli katma değerin artıp, yabancı katma değerin azaldığı ülkeler ile diğerleri açısından tersi durumun gerçekleştiği bir şekildedir. Ne yazık ki Türkiye açısından ihracatta yabancı katma değer payı artmıştır ve bu sadece 2001 ve 2011 yılları için değil, söz konusu yıllar arasındaki genel görünüm itibariyle geçerlidir.

\section{Grafik 7: İmalat Sanayinde Yaratılan Katma Değer (1995 ve 2008, \%)}

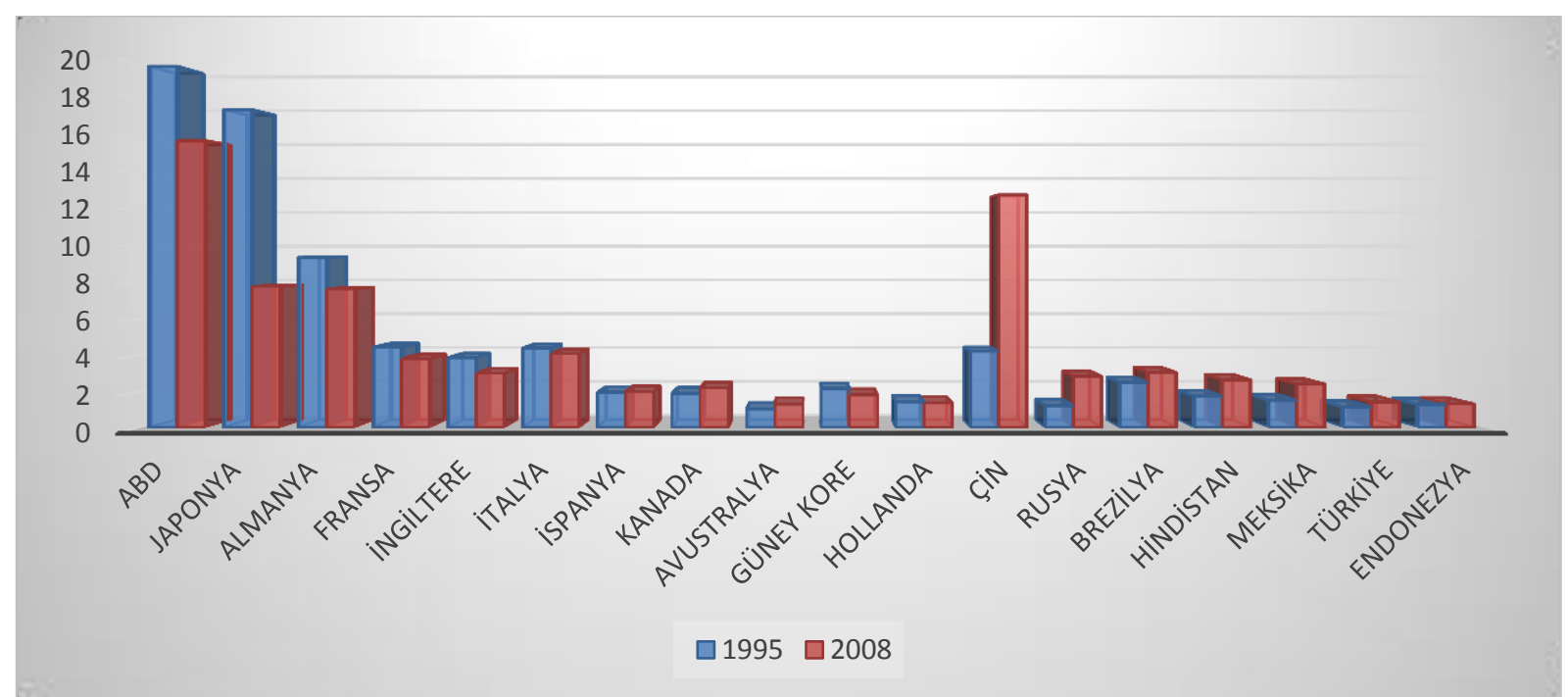

Kaynak: M. P. Timmer, et. al., "Slicing Up Global Value Chains", Journal of Economic Perspectives, 28(2), 2014.

İhracatta katma değer incelemesi özellikle dünya ekonomisi pazar payının elde edilmesi, güçlü bir dış ticaret aktörü haline gelme ve önemli döviz kazanımları elde etme açılarından gereklidir. Bu incelemede imalat sanayi odak noktasıdır. Bu konuya yönelik literatürde önemli referans noktalarından birini oluşturan Timmer, 2014 çalışmasına ilişkin ülkeler açısından durum Grafik 6'da gösterilmiştir. 1995 ve 2008 yıllarındaki durum karşılaştırılmıştır. İspanya, Kanada, Avusturalya, Çin, Rusya, Brezilya, Hindistan, Meksika ve düşük de olsa Türkiye'de imalat sanayi katma değerinin 2008 yılı itibariyle arttığı görülmektedir. Türkiye açısından artışın düşük kalması pazar payının elde edilmesi açısından ek önlemler, teşvik ve stratejiler ile acele edilmesi gereğini göstermektedir. 


\section{BULGULAR VE TARTIŞMALAR}

\subsection{Gelişmiş Ülke Ekonomik Aktörleri Arasındaki Serbest Ticaret Anlaşmalarında Türkiye'nin Durumu: Transatlantik Ticaret ve Yatırım Ortaklığı (TTIP), Kapsamlı Ekonomi ve Ticaret Anlaşması (CETA) ve Kapsamlı ve Yenilikçi Trans Pasifik Yatırım Ortaklığı Anlaşması (CPTPP) Örnekleri}

Transatlantik Ticaret ve Yatırım Ortaklı̆̆ı, ABD ve AB arasında müzakereleri 2013 yılında başlayan ve 2017 yılında sonlandırılması planlanan ancak çeşitli sorunlar nedeniyle şu anda askıda bekletilen bir kapsamlı serbest ticaret anlaşmasıdır. TTIP'nin genel olarak önemi şu şekilde sıralanabilir (EU Commission 2013 ve OECD 2013'den aktaran Çelebi, 2013: s. 219):

-Anlaşma serbest ticaret alanının oluşturulması açısından çok ciddi bir girişimdir.

-Anlaşma ile taraflar ( $A B D$ ve $A B$ ) daha önce ticaret konusunda değinilmemiş konular ile ilgili ayrıntılı bağlayıcı düzenleme ve kurallara yer vererek dünya ticaretinde hâkim konuma ulaşmak istemektedir.

TTIP'nin, $A B D$ ve $A B^{\prime}$ nin geçen 20 yılda birbirlerinin ticaret piyasalarındaki paylarının düşüşünü telafi etmek, büyümelerini hızlandırmak ve çok taraflı ticaret sistemi ile küresel standartlardaki etkilerini artma amaçlı gerçekleştirilmesi planlanan bir anlaşma olduğu görülmektedir (Majchrowska, 2017, s. 158). Anlaşmanın, gümrük tarifelerinin çok ötesinde bir sınır ötesi zemine oturtulması ile küresel ticaretin tabi olacağı ve yeni kurallara emsal teşkil edeceği beklenmektedir (Akman, 2014: 2). TTIP anlaşması mal ve hizmet ticaretinin yanı sıra transatlantik ticari ilişkileri açısından önemli bir konu olan doğrudan yabancı yatırımlar üzerinde yoğunlaşmaktadır (Çelebi, 2013: s. 220). TTIP anlaşmasının ticari ilişkilerin yanı sıra önemli bir boyutu da karşılıklı doğrudan yabancı sermaye yatırımlarıdır. Taraflar arasında yatııı stoku yaklaşık olarak 3.7 trilyon dolara ulaşmış, dünyadaki toplam sermaye yatırımlarının \%57'si $A B$ ve $A B D$ 'ye yapılırken, $A B$ ve $A B D$ 'nin dış yatırımlardaki toplam payı \%71'i bulmuştur (Akman, 2014: 5). Ayrıca, ABD yatırımlarının yarıdan fazlası $A B$ 'ye yapılmakta, bu oran $A B$ açısından toplam dış yatıımların yaklaşık \%30'una denk gelirken, $A B D^{\prime}$ ye gelen toplam sermayenin $1 / 3$ 'ü ise $A B$ çıkışlı olmaktadır (Akman, 2014: 5). Durum böyle olunca diğer çok sayıda etkenle birlikte, AB ve ABD arasında, TTIP minvalinde bir bütünleşme kaçınılmaz olmuştur.

TTIP ile ilgili çeşitli çekince ve eleştiriler şu şekilde sıralanabilir (Sülün, 2017: 126):

-Müzakereler şeffaf olamamaktadır ve çeşitli sorunlu konuları (tüketici sağlığı, çevre, tarım sektörü vb.) içermektedir.

-Müzakere ve karar süreçleri yeterince kapsayıcı değildir, tüm üye devletlerin görüş ve kaygılarını yansıtmamaktadır. Bu açıdan taraf olan ülkelerin parlamentolarından onay alınması ve bu ülkelerde referandum düzenlenmesi gerekmektedir.

-Müzakereler birkaç yıl daha sürebilecektir.

-Anlaşmaya ilişkin düzenlemelerde yönetişim çabasının buradaki aktörler (çok uluslu şirketler ve çıkar grupları) açısından olumsuzluklara neden olabileceği düşünülmektedir.

Kapsamlı Ekonomik ve Ticaret Anlaşması, AB ile Kanada arasında 30 Ekim 2016 tarihinde imzalanan ve yürürlüğe giren bir serbest ticaret anlaşmasıdır. G7 üyeleri arasında imzalanan ilk kapsamlı ticaret anlaşması özelliği taşıyan CETA, çok taraflı ticari ilişkilere yeni bir adım olmuş, bu şekilde gelişmiş ülkeler arasında ticari anlaşmaların imzalanabileceğine ilişkin bir örnek oluşturmuş ve çok yönlü ekonomik ve ticari boyutların ortaya çıkmasında bir öncü rolünü üstlenmiştir (Majchrowska, 2017, s. 159).

Kapsamlı ve Yenilikçi Trans Pasifik Yatırım Ortaklığı Anlaşması, daha önce Trans Pasifik Yatırım Ortaklığı olarak tasarlanan ve müzakere edilen ancak 2017 yılı itibariyle müzakere üyelerinden ABD’nin çekilme kararının ardından akıbeti belirsizleşen ancak $A B D$ dışındaki üyeler tarafından yeni bir açııımla müzakere edilerek kabul edilen anlaşmadır.

ABD'nin Ocak 2017'de çekilmesinden sonra Avusturalya, Brunei Darussalam Sultanlığı, Kanada, Şili, Japonya, Malezya, Meksika, Peru, Singapur, Viyetnam ve Yeni Zellanda, Kasım 2017'de müzakerelere tekrar başlayarak 23 Ocak 2018'de sonlandırmışlardır. Trans Pasifik Ortaklığı Anlaşmasının içlerinde yatırım ve telif hakları gibi konuları içeren 22 maddesi askıya alınarak yeni anlaşma olan CPTTPP tasarlanmıştır. Sorun oluşturabileceği düşünülen bu maddelerin daha sonra anlaşmaya dahil edilmesine karar verilmiştir (Yeni Zelanda Dış İlişkiler ve Ticaret Bakanlığı, Serbest Ticaret Anlaşmaları Portalı, $\quad$ https://www.mfat.govt.nz/en/trade/free-trade-agreements/free-trade-agreements-concluded-but-not-inforce/cptpp/tpp-and-cptpp-the-differences-explained/).

TPP'nin aksine, CPTPP'de herhangi bir ülkenin sözleşmeyi yürürlüğe koymadan önce onaylaması şartı aranmamaktadır. Anlaşmanın yürürlüğe girebilmesi için imzalayan ülkelerin en azından yarısının onaylaması gerekmektedir ki bunun 8 Mart 2018 'de olması beklenmektedir.

Anlaşma ismindeki "yenilikçilik" ifadesine, özel sektörün maliyetlerinin azaltılmasının çok ötesinde yenilikler getirmesinden dolayı yer verilmiştir. Söz konusu yenilikler içinde Asya - Pasifik Bölgesi içerisinde çok yüksek istihdam ve çevresel 
standartların getirilmesi bulunmaktadır. Anlaşma; üye ülkelerin işçi ücret ve güvenlik uygulamalarının ve kanunlarının düzenlenmesinde söz sahibi olmalarını garanti etmeyi, hizmet ve dijital sektörlerin büyümesine yönelik destek sağlamayı, özel sektörün her ölçeğindeki firmalara ticaret desteği vermeyi, devlet sözleşmelerine teklif vermeye yönelik her türlü fırsatı sağlamayı ve artan ticaret fırsatlarından yararlanmayı sağlamayı taahhüt etmektedir (Yeni Zelanda Dış ilişkiler ve Ticaret Bakanlığı, Serbest Ticaret Anlaşmaları Portalı, https://www.mfat.govt.nz/en/trade/free-trade-agreements/free-tradeagreements-concluded-but-not-in-force/cptpp/tpp-and-cptpp-the-differences-explained/).

\subsection{Anlaşmaların Türkiye'nin Dış Ticaretine Olası Etkileri}

İktisadi bütünleşme uygulamalarının hangi biçimde gerçekleşirse gerçekleşsin bütünleşmeye dahil olmayan ülkeler açısından dezavantajlı durumlar yaratması kaçınılmazdır. Bununla birlikte bütünleşme içinde olunmasına rağmen bazı şartların gelişmesi durumunda olumsuzluklar ve dezavantajlı konum yine de ortaya çıkabilmektedir. Son dönemde dış ekonomik ilişkiler çerçevesinde gerçekleşen ve boyutları öncekilerden çeşitli açılardan farklı olan serbest ticaret anlaşmaları ile Türkiye'nin söz konusu anlaşmalar karşısındaki durumu buna örnek teşkil etmektedir.

Son dönem serbest ticaret anlaşmaları; öncelikle anlaşmayı imzalayan ülkelerin ekonomik güçleri açısından daha sonra da Türkiye'nin hemen hiçbiri ile ikili serbest ticaret anlaşması olmaması ve anlaşma olmasa da örneğin $A B$ ile $G B$ içinde olunmasının zorunlu kıldığı durumlardan ötürü Türkiye dış ticareti ve ekonomik ilişkileri açısından büyük ölçüde olumsuzluk içermektedir.

Bu açıdan bu başlık altında yürürlüğe girmesi halinde Türkiye'yi olumsuz etkileyeceği ifade edilen TTIP, ardından da imzalanarak yürürlüğe girdiği ve TTIP gibi sonuçları olacağı beklendiği için CETA ve son olarak da aralarında Türkiye ile ticari ilişkilerinin olduğu ülkeler tarafından imzalanmış ve yürürlüğe girmek üzere olan CPTPP anlaşmasının etkilerinden yola çıkılarak, yapılmış olsun ya da olmasın serbest ticaret anlaşmalarının olumlu ve olumsuz olabilecek yanları ele alınacaktır.

Türkiye'nin AB ile Gümrük Birliği dolayısıyla özel bir ilişkisi bulunmaktadır. AB'ye tam üye olunmadığı sadece Gümrük Birliği ilişkisi olduğundan dolayı ne yazık ki Türkiye'nin ortak ticaret politikalarını uygulama ve $A B^{\prime}$ nin diğer ülkelere yönelik tercihli ticaret sistemini kabul etme zorunluluğu ortaya çıkmaktadır (Aydın, 2004). Bu durum AB'nin anlaşmasının olduğu ancak Türkiye'nin olmadığında söz konusudur. Serbest ticaret anlaşmalarının Türkiye'nin daha esnek olabilmesinden ve çıkarlarını daha iyi koruyabilmesinden dolayı Gümrük Birliği'nden daha avantajlı olduğu - ki Gümrük Birliği nedeniyle de yapmış olsa yapılan anlaşmalarda sanayi ve ticaret politika öncelikleri gözetilebilmektedir, ifade edilmektedir (Yılmaz, 2011: 246; Koçtürk ve Kocaefe, 2014: 66). Gümrük Birliğinden dolayı çıkarları ve kazanımları bütünüyle korumaya yönelik bağımsız bir serbest ticaret anlaşmasının yapılmasının tam anlamıyla mümkün olmadığı ifade edilmektedir (Türkcan ve Pişkin, 2014: 26).

Gümrük Birliği Anlaşması ile Türkiye, $A B^{\prime}$ nin üçüncü ülkelerle uygulamakta olduğu gümrük mevzuatını uygulamayı taahhüt etmiş, dolayısıyla $A B^{\prime}$ nin anlaşma imzaladığı ancak Türkiye'nin anlaşmasının olmadığı ülkeler (örneğin Cezayir, Meksika gibi) Türkiye'ye gümrüksüz mal satma olanağına sahip olmuştur (Güllü: s. 100). Bu kategorideki ülkeler ile Türkiye'nin serbest ticaret anlaşması imzalamak gibi bir zorunlulukları bulunmamakta, bu durum haksız rekabete yol açmakta, özellikle de büyük ekonomik aktörler arasındaki (örneğin $A B$ - ABD arasındaki TTIP gibi ya da $A B^{\prime}$ nin diğer önemli ekonomik ülkelerle arasındaki STA'lar) anlaşmalardan olumsuz anlamda etkileneceği beklenmektedir (Güllü, s.100).

\section{Grafik 8: AB'nin STA'sının Olduğu Ancak Türkiye'nin Olmadığı Ülkeler Açısından İhracatın İthalatı Karşılama Oranı (2007-2017, \% ort.)}

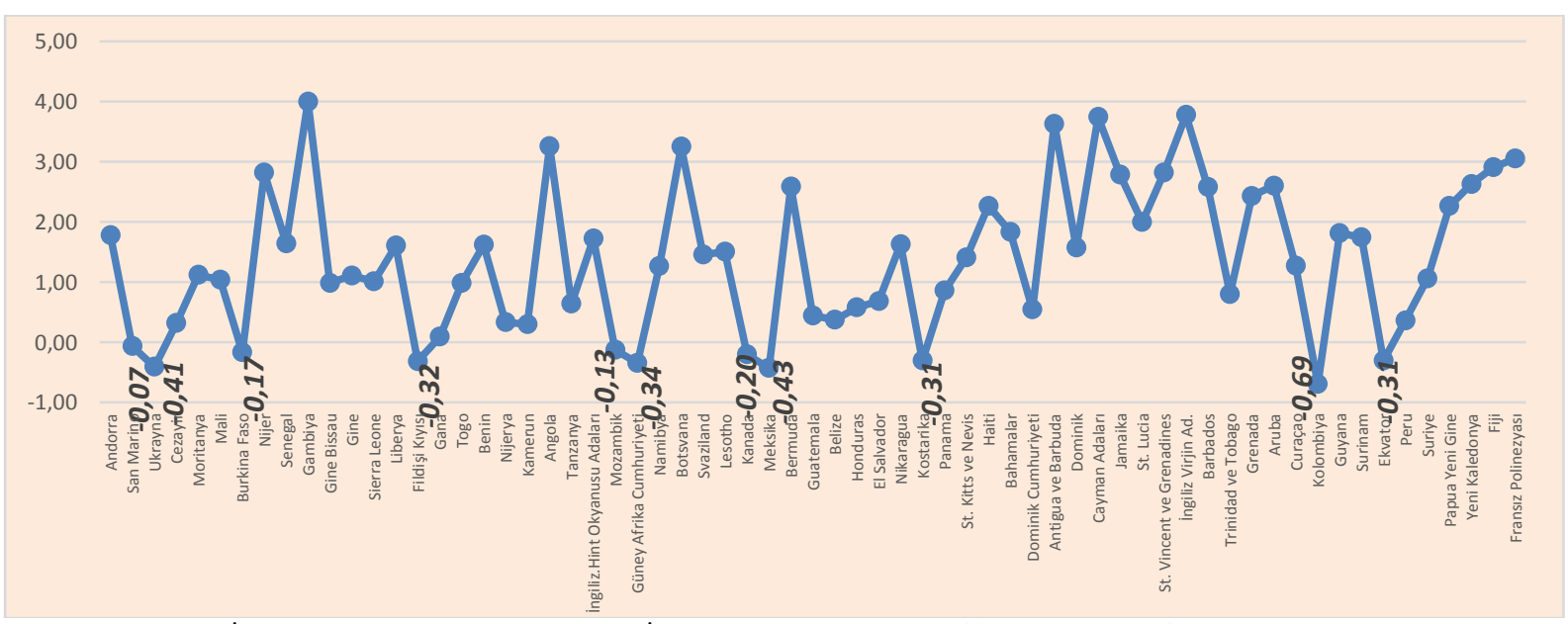

Kaynak: Türkiye İstatistik Kurumu, Dış Ticaret İstatistikleri, 2017, http://www.tuik.gov.tr/PrelstatistikTablo.do?istab id=630; http://www.tuik.gov.tr/PrelstatistikTablo.do?istab id=629 
Grafik 8'de AB'nin STA'sının olduğu ve Türkiye'nin anlaşmasının bulunmadığı ancak Gümrük Birliği dolayısıyla Türkiye açısından eşit olmayan koşullarda dış ticaret ilişkisinin kurulduğu ülkeler açısından ihracatın ithalatı karşılama oranları 2007 ve 2017 yılları arasındaki veriler çerçevesine ortalama olarak verilmiştir. Söz konusu incelemede; San Marino, Ukrayna, Burkina Faso, Fildişi Kıyısı, Mozambik, G. Afrika, Kanada, Meksika, Kosta Rika, Kolombiya ve Ekvator ile ihracatın ithalatı karşılama oranı ithalat lehine negatiftir. Dış ticaret açısından söz konusu ülkeler ile rekabet dezavantajımız söz konusudur.

Grafik 9: 2017 Yılı İtibariyle AB'nin STA'sının Olduğu Ancak Türkiye’nin Olmadığı Ülkeler Açısından ỉhracatın İthalatı Karşılama Oranı (\%)

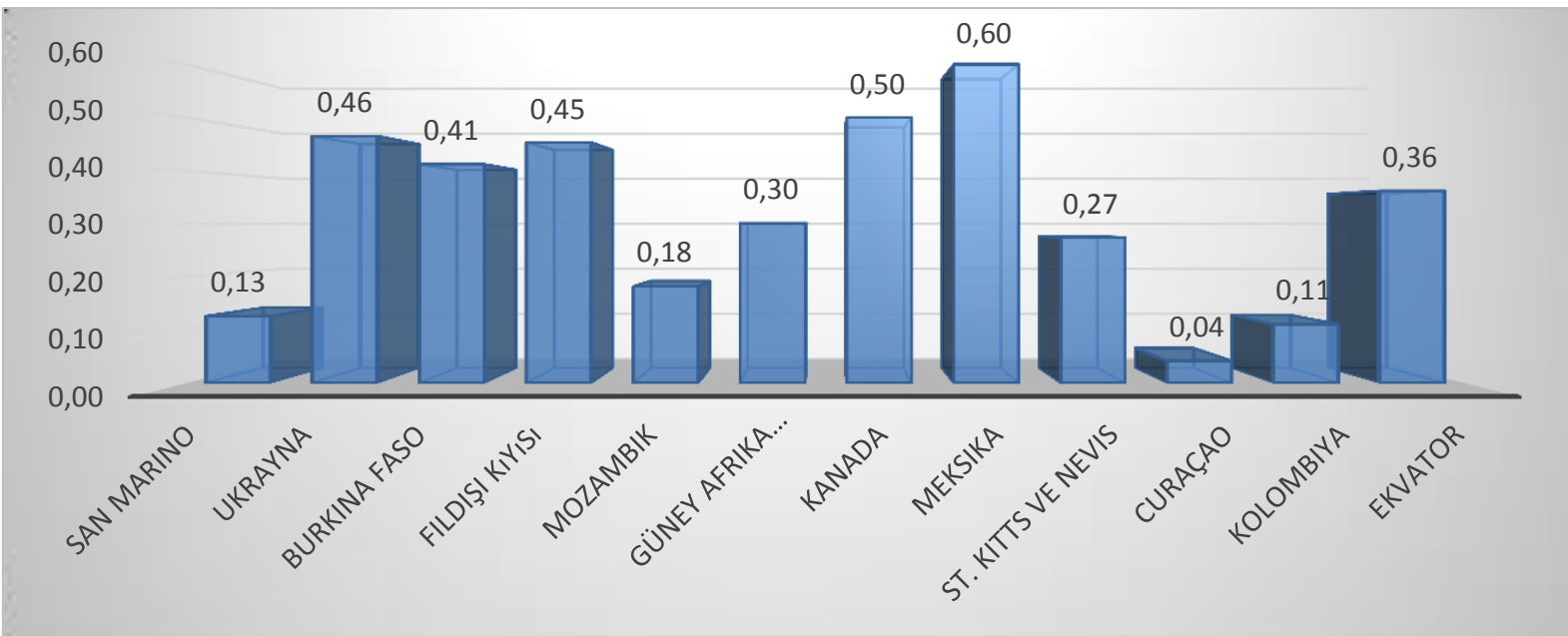

Kaynak: Türkiye İstatistik Kurumu, Dış Ticaret İstatistikleri, 2017, http://www.tuik.gov.tr/PrelstatistikTablo.do?istab_id=630; http://www.tuik.gov.tr/PrelstatistikTablo.do?istab id=629

Grafik 9'da da 2017 yılı itibariyle dış ticarette rekabet dezavantajımızın oluştuğu ülkeler görülmektedir. Ülke sayısına bir ülke daha eklenmiştir. Bu ülkelerden Kanada ve Meksika'nın ekonomik olarak güçleri, Kanada'nın AB ile arasında gerçekleştirdiği ve birazdan değinilecek olan CETA ile Kanada ve Meksika'nın da aralarında olduğu ülkeler tarafından imzalanan ve yürürlüğe girmesi yakın olan CPTPP düşünüldüğünde Türkiye'nin dezavantajının daha da artacağı düşünülmektedir.

$A B$ ile Gümrük Birliği içinde olunmasından dolayı Türkiye açısından eğer özellikli bir strateji yürütülmez ya da önlem alınmaz ise büyük çaplı sorunların ortaya çıkacağı iki durum da TTIP ve CETA Anlaşmalarıdır. Bu anlaşmalardan TTıP askıdadır ancak iptal edilmemiştir. Ancak CETA imzalanmış ve yürürlüğe girmiştir.

TTIP hem fırsat hem de sorun yaratmaktadır. Müzakere içindeki taraflar için uluslararası ekonomi ve politika zeminlerindeki yerlerini sağlamlaştırma ve artırma fırsatı yaratmaktadır. Bu anlaşma uluslararası ekonomik ilişkiler ve bölgesel ticaret anlaşmaları açısından yeni standartların yaratılması açısından potansiyele sahiptir (Czarny and Felbermayr, 2017, s. 3). Anlaşmanın yürürlüğe girerse $A B$ genelinde ortalama \%2'lik bir büyüme kazancı sağlayacağı yapılan çalışmalardan ortaya çıkmaktadır. Bununla beraber söz konusu anlaşmanın, anlaşma tarafı olmayan üçüncü ülkeler açısından özellikle de ihraç mallarındaki çakışma durumunda zararlı olacağı da çalışmalarda bulgulanmıştır (Felbermayr, 2016, s.18).

TTIP dışında kalan ülkelerin ekonomik büyümelerinin anlaşmadan dolayı olumsuz etkileneceği hesaplanmış olup, anlaşmanın sektörel etkisi transatlantik ortak pazarın ticari ilişkilerdeki maliyetleri önemli ölçüde düşürecek olmasından kaynaklanmaktadır (Hasanov ve Macit, 2015: 18). TTIP'nin sağlayacağı serbest dolaşım nedeniyle, ABD'nin AB'ye satacağı mallar, $A B$ üzerinden Türkiye'ye geldiğinden söz konusu gümrük vergileri $A B^{\prime}$ de tahsil edilecek ve bu durum ise Türkiye'nin ticaret ve rekabet güncünü ve pazar kabiliyetini daraltacak, gümrük gelirlerini düşürecektir (Üstün, 2013: 4).

Yapılan analizler neticesinde Türkiye'de, TTIP Anlaşması'ndan en çok etkilenecek sektörler; \%16.2 ile motorlu kara taşıtı ve diğer ulaşım araçları imalatı, \%10.77 ile ana metal ve metal eşya sanayi, \%6.69 ile kok kömürü ve rafine edilmiş petrol ürünleri imalatı, \%6.44 ile elektrik ve optik ürünler imalatı, \%6.24 ile plastik ve kauçuk ürünler imalatı ve \%6.23 ile başka yerde sınıflandırılmayan makine ve teçhizat sanayi olacaktır (Hasanov ve Macit, 2015: 19). Sonuç olarak olası durumda ihracat gelirlerinde azalma yaşanması kaçınılmazdır. Sektörel etkiler üretim düşüşlerini ortaya çıkaracak bu da şirket kârlılıklarını ve istihdamı olumsuz etkileyecektir. Ayrıca kârlılıkları düşen şirketler haliyle daha düşük vergi ödeyecek ve devlet açısında gelirler de azalacaktır (Arslan ve Çaşkurlu, 2016: s.667). 
TTIP çerçevesinde yapılan açıklamalar ve çalışmalarda ifade edilen olumsuzlukların, fiili durumda gerçekleşmiş hali CETA'da ortaya çıkabilir. Anlaşma imzalanmıştır. CETA, AB ve Kanada arasında ticareti kolaylaştıran, gümrük vergilerini ortadan kaldıran ve böylelikle büyük bir serbest ekonomik ve ticari alan yaratacak bir anlaşmadır (Akbalık, 2017). Tüketiciler açısından daha çeşitli ürün kullanımına yol açması ve teknoloji transferi yoluyla özel sektörde uzmanlaşmanın artması olanağına sahip olmasına karşı Türkiye'nin anlaşma tarafı olmadığı tüm STA'larda olduğu gibi çeşitli olumsuzlukları da ortaya çıkarması olası gözükmektedir (Gullu, Kilic, Sanlioglu 2017, 280). Bu anlaşma yoluyla Kanada'da üretilen ürünler $A B$ üzerinden gümrüksüz bir şekilde Türkiye'ye girebilecek ancak tersi durum Türkiye'de üretilen ürünleri Kanada'da gümrük vergisi ile karşı karşıya bırakacaktır. Bu durumun önlenmesi açısından Türkiye Kanada ile STA müzakeresi için talepte bulunmuş ancak hiçbir yanıt alamamıştır (Erem, 2016).

Gümrük Birliği ilişkisi dışında Türkiye'nin son dönemde gerçekleştirilen çok taraflı STA anlaşmalarından da etkilenmesi söz konusudur. Bu anlaşmalardan en önemlisi çok taraflı CPTPP Anlaşmasıdır. Bu anlaşmaya taraf olan ülkelerden Kanada, Japonya ve Meksika Türkiye'nin ticaret partnerleri arasındadır. Özellikle Japonya'nın Türkiye açısından ithalat payı yüksektir. Kanada'nın ayrıca önemi daha önce ifade edildiği gibi AB ile STA yapmış olmasıdır.

Grafik 7: Önemli Ekonomik Aktörlerin Türkiye Dış Ticaretindeki Payları (2007 - 2016 ort.)

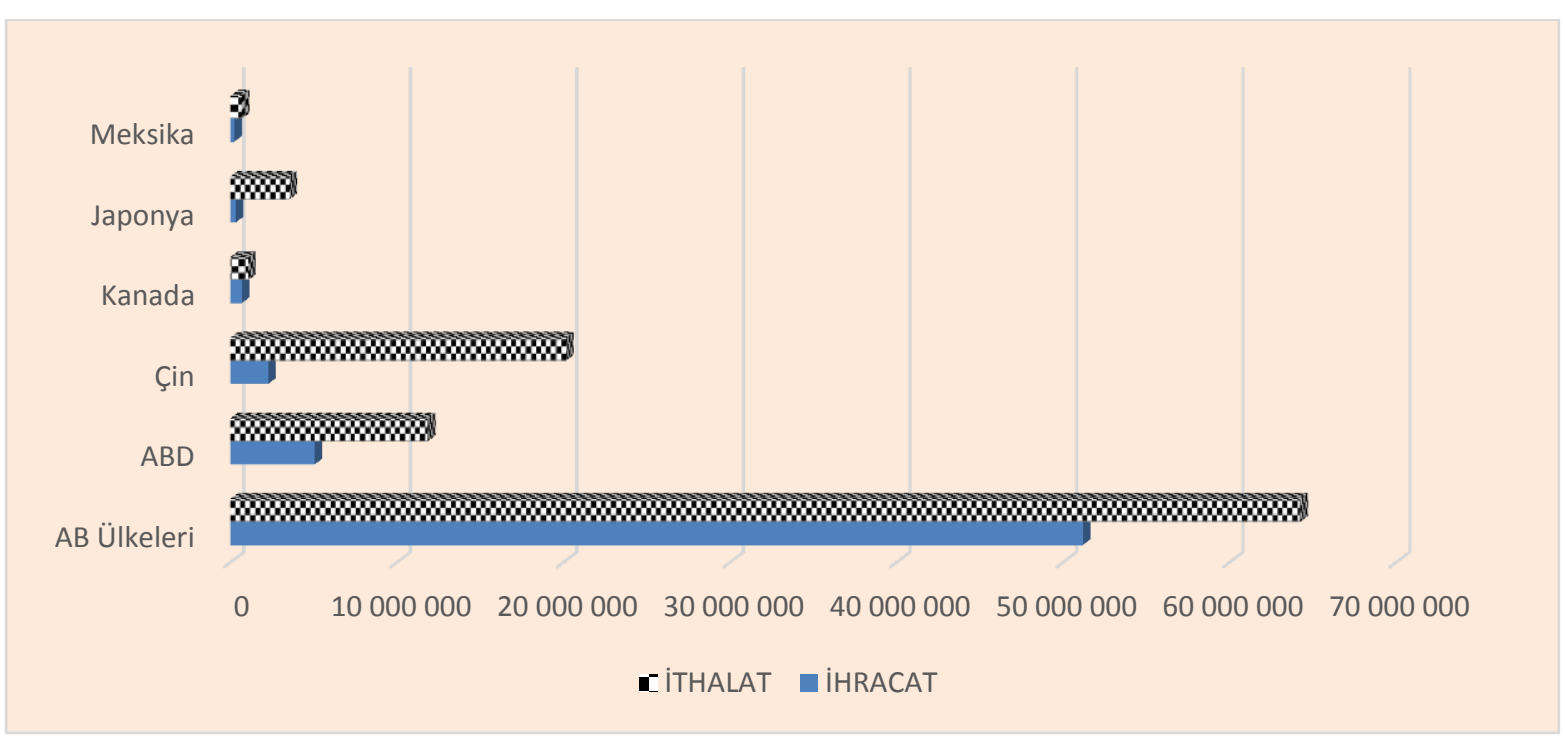

Kaynak: TÜiK, http://www.tuik.gov.tr/PrelstatistikTablo.do?istab id=1545; http://www.tuik.gov.tr/PrelstatistikTablo.do?istab id=1546

Grafik 7'de Türkiye'nin ihracat ve ithalatında ülke payları görülmektedir. Buna göre ihracatın ve ithalatın büyük kısmı Euro bölgesine yapılmakla birlikte, Çin çok önemli bir ithalat ülkesi ve ABD de hem ithalat hem de ihracatta pay sahibidir. Her ne kadar son yıllarda yeni ihracat pazarları ortaya çıkmış olsa da $A B$ ve $A B D$ pazarı birlikte değerlendirildiğinde Türkiye'nin hala en önemli dış ticaret pazarı olma özelliğini korumaktadır ${ }^{1}$.

Tablo 6: Türkiye'nin Toplam İhracat ve İthalatı İçinde Ülke Payları

\begin{tabular}{|l|c|c|}
\hline & IHRACAT & ITHALAT \\
\hline AB Ülkeleri & $38.24 \%$ & $30.95 \%$ \\
\hline ABD & $3.79 \%$ & $5.71 \%$ \\
\hline Çin & $1.71 \%$ & $9,71 \%$ \\
\hline Kanada & $0.52 \%$ & $0.52 \%$ \\
\hline Japonya & $0.24 \%$ & $1.71 \%$ \\
\hline Meksika & $0.17 \%$ & $0.33 \%$ \\
\hline
\end{tabular}

Kaynak: TÜik, http://www.tuik.gov.tr/PrelstatistikTablo.do?istab_id=1545; http://www.tuik.gov.tr/PrelstatistikTablo.do?istab id=1546

\footnotetext{
${ }^{1}$ Türkiye İhracatçılar Meclisi tarafından yapılan İhracatçı Eğilim Araştırması sonuçlarına göre 2015'in 2. çeyreğinde ihracatçıların girmeyi hedefledikleri 5 ülke arasında toplam açııından ABD \%15.4'lük bir orana sahip olup, Rusya'nın ardından 2. sırada yer almakta ve ilk 15 ülke arasında $5 \mathrm{AB}$ ülkesi yer almaktadır. Diğer taraftan ihracatçıların en büyük sorunlarının \%61.4 ile döviz kuru olduğu görülmektedir (TiM, 2015: 18). Bahsi geçen araştırma dahi anlaşmanın etkilerinin ne boyutta olduğu hakkında fikir vermektedir.
} 
Tablo 6'da toplam ihracat ve ithalat içindeki paylar görülmektedir. $A B$ ve $A B D$ her iki ticaret faaliyetinde de önemli bir paya sahiptir. Bunlara Kanada'nın AB ile STA'sından dolayı eklenmesi toplamda payların artmasına neden olmaktadır. Ancak burada dikkat edilmesi gereken rakamların ülke paylarını gösterdiğidir. Diğer taraftan toplam ithalat ve ihracat karşılaştırması yukarıda Grafik 7'de de işaret edildiği üzere ithalat lehinedir.

\section{SONUÇ}

Türkiye açısından büyüme ve gelişimin en önemli kısımlarından birisi dış ticaretteki lehte gelişmelerdir. İthalatın ihracatı aşma durumunu ifade eden dış ticaret açıkları gerekli durumlarda yapılabilmektedir ancak özellikle strateji yanlışlarından kaynaklanan açıklar döviz açıklarına neden olduğu gibi makroekonomik zayıflıklara yol açarak uzun dönemli zararlar ortaya çıkabilmektedir.

Türkiye açısından dış ticaret stratejisi açısından düşünülmesi gereken en önemli hususlardan biri, uluslararası ekonomik ilişkilerin günümüzde geldiği noktadaki stratejik ticaret ortaklıkları ve ekonomik bütünleşmelere hazırlıklı ve/veya paydaş olmaktır. Bunun en temel örneği $A B$ ile Türkiye arasındaki ilişkidir. GB anlaşması dolayısıyla Türkiye'nin ortak ticaret politikası araçlarını kendi ülke tercihlerine göre belirleyememesi ve bundan dolayı $A B^{\prime} y e$ tek taraflı bağımlılık içine girmesi gibi olumsuz bir durum içinde olması söz konusudur (Emre Orhan..., s. 138).

İçeriklerini aynen kabul etme ve uygulama zorunluluğu olmasa da Türkiye sadece AB'nin yapmış olduğu STA'lara taraf ülkelerle serbest ticaret anlaşması imzalayabilmektedir (Doğan ve Uzun, 2014: 331). Üçüncü ülkelerle $A B$ arasında yapılan STA'lardan sonra Türkiye'nin söz konusu ülkelerle anlaşma yapıncaya kadar geçen süre aralığında, iç pazarı üçüncü ülke tarafından yapılacak ihracata açık hale gelmekte ancak aynı şekilde Türkiye'nin söz konusu ülkelere ihracat pazarı olarak ulaşma şansı olmamakta, iç pazardaki sektör ve şirketler rekabet baskısı altında kalmaktadır (Doğan ve Uzun, 2014: 333334). Söz konusu durumun ortaya çıkardığı sorunların önlenmesi açısından yapılabilecekler şu şekilde sıralanabilir (Doğan ve Uzun, 2014: 342):

-Türkiye'nin AB üçüncü bir ülkeyle STA gerçekleştirmeyi planladığında bu konuda önceden bilgilendirilmesi gerekmektedir.

-Türkiye'nin AB'nin herhangi bir ülkeyle gerçekleştirmeyi planladığı STA müzakerelerine ilgili ülkeyle aynı zamanda başlamasının sağlanması gerekir.

-Türkiye'nin STA'ların ortaya çıkarması olası zararlarını ve bunlara karşı alınabilecek önlemleri içeren ve "etki analizi" olarak adlandırılan raporlara dahil edilmesi gerekmektedir. Buna ek olarak ya da alternatif olarak Türkiye ile STA imzalamayı istemeyen ülkelere karşı telafi edici vergi uygulamasına (1/95 sayılı Ortaklık Konseyi Kararı'nın 16/3 ve 58/2 maddeleri) olanak tanınması gerekmektedir.

Son dönemde büyük ekonomik aktörler tarafından gerçekleştirilmesi planlanan ve gerçekleştirilen büyük çaplı ve yeni nesil STA'lar, söz konusu anlaşmalara müzakere tarafı olmayan Türkiye'yi anlaşmaya taraf ülkelerle arasındaki şu veya bu şekildeki ticaret ilişkileri çerçevesinde olumsuz etkileme potansiyeline sahiptir. TTIP, CETA ve CPTPP anlaşmaları bunlara örnek oluşturmaktadır.

Avrupa Birliği tarafından hazırlanan mega bölgesel ticaret anlaşmaları, gelişmekte olan ülkeler arasından üretici kayıpları yaratma potansiyeline sahiptir (Felbermayr and Aichele, 2015, s. 31). AB ve ABD arasında gerçekleştirilmesi planlanan TTIP anlaşmasının potansiyel zararlarııın ortadan kaldırılması ya da en azından azaltılması açısından üç temel konuda öneri getirilmektedir (Felbermayr and Aichele, 2015, s. 32):

$-A B$ ve $A B D$ nin mümkün olduğunca karmaşık menşei kuralları getirmekten kaçınmaları gerekmektedir. Bunun yerine mümkün olduğu ölçüde malların serbest hareketini sağlamaları gerekmektedir.

-Tarife engellerinin olmadığı alanlarda, anlaşmaların mümkün olduğunca standartların karşılıklı kabulünü üçüncü ülkeleri de dahil edecek şekilde düzenlemeleri gerekmektedir. Bu durum karşılıklı kabul anlaşması uygulamalarının üreticilerin uyruğuna bağlı olarak değil, menşeinden bağımsız bir ürünün anlaşmanın taraflarını standartları yönünden tatmin edip etmediğine bağlı olarak yönetilmesi gereğini ifade etmektedir.

-Modern ticaret anlaşmalarının düzenleyici yakınlaştırma ve uyumlaştırma özelliklerini taşıması gerekmektedir.

Gelişmekte olan ve örneğin yukarıda ifade edilen TTIP'nin yürürlüğe girmesi halinde bu anlaşmaya taraf olmayan ülkelerin karşılaşacağı zararların engellenmesi açısından uygulanması etik ve rasyonel olan unsurlar çalışmalarda ifade edilmektedir. Ancak bu unsurların müzakerelerde dikkate alınmaması ve / veya örneğin Türkiye'nin kendisini bu veya diğer anlaşmalar karşısında yeterli şekilde koruyacak önlemeleri almaması kendi dış ticaret politikamızın haricinde kayba uğramamamıza neden olabilecektir. 


\section{Grafik 8: Türkiye Açısından Müzakere Üyesi Olmadı̆̆ı STA'lar İçin Alternatif Çözümler}

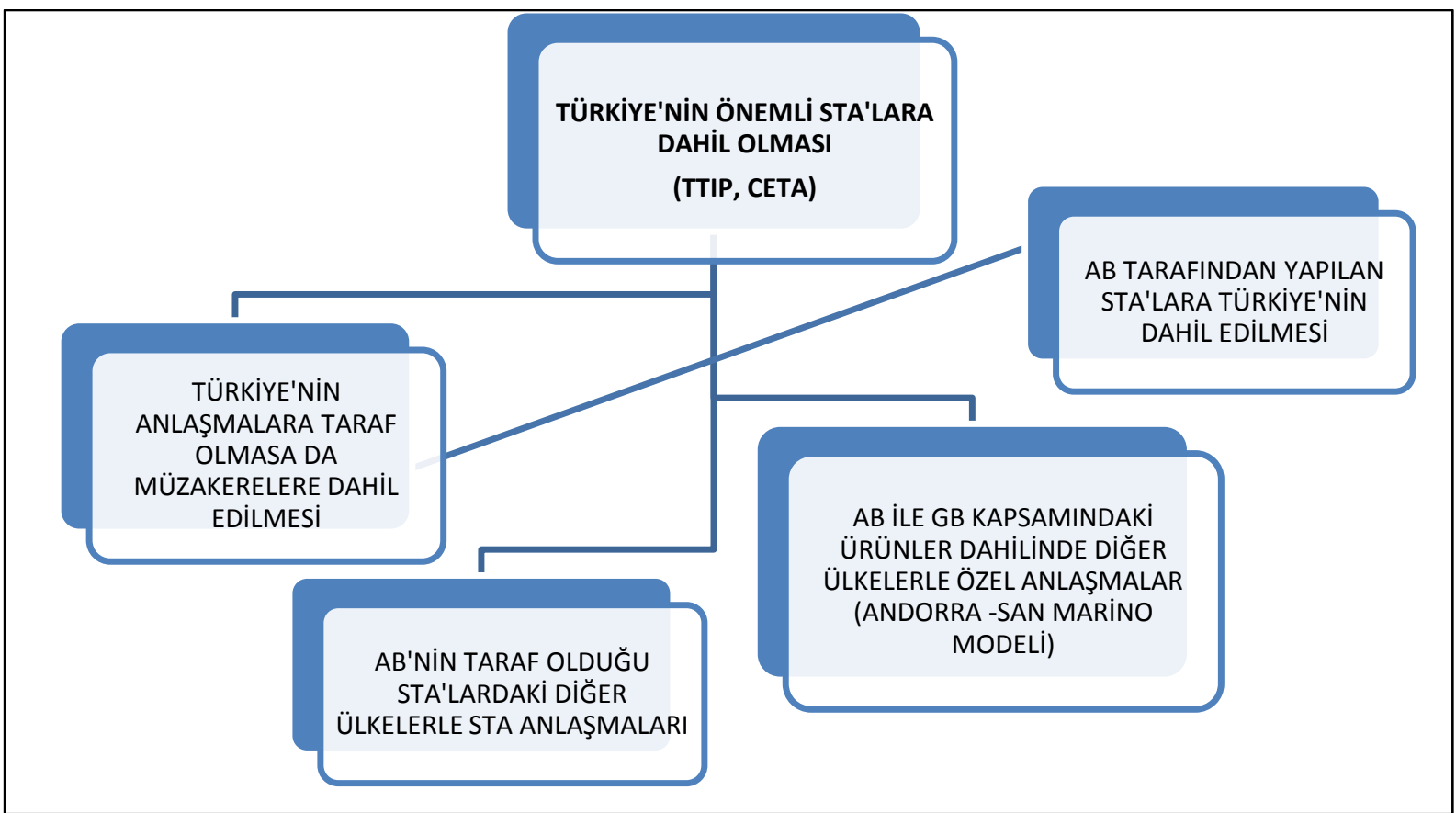

Kaynak: (Akman, 2014: 19)'dan hareketle tarafımca oluşturulmuştur.

Grafik 8'de müzakere üyesi olmadığı STA'lar açısından Türkiye'nin potansiyel olumsuzluklarla karşılaşmaması açısından uygulanabilecek çeşitli çözümler yer almaktadır. Bunlar özellikle AB ile GB içinde olunmasından dolayı Türkiye tarafından atılması gereken adımlara örnek teşkil etmektedir. Bunun dışında CPTPP gibi üye ülkelerle ticaret ortağı olunması durumunun olduğu anlaşmalarda ise ikili ticaret anlaşmaları ya da benzer düzenlemelere gidilmesi Türkiye lehine olacaktır.

\section{KAYNAKLAR}

Ahmed, S., Maximiliano A., Michele R., (2015). Depreciations Without Exports? Global Value Chains and the Exchange Rate Elasticity of Exports. World Bank Policy Research Working Paper 7390.

Akbalık, C., (2017). AB ile Kanada Arasındaki Ticaret Anlaşması CETA Protesto Ediliyor", Paris - BíA Haber Merkezi 17 Şubat 2017 , https://www.mfat.govt.nz/en/trade/free-trade-agreements/free-trade-agreements-concluded-but-not-in-force/cptpp/tpp-and-cptpp-thedifferences-explained/Erişim 01.02.2018

Akça, E.E., Bal H., Çağlayan M.H., (2017). The Effects of The Customs Union on Trade Between Turkey and European Union. LAÜ Sosyal Bilimler Dergisi (VIII-I), 1-18.

Akman, M.S., (2014). AB-ABD Transatlantik Ticaret ve Yatırım Ortaklığı: Türkiye Açısından Bir Değerlendirme. Ankara Avrupa Çalışmaları Dergisi Cilt:13, No:1, 1-29.

Aktaş, C., Güven D., (2003). Gümrük Birliği Sonrasında Türkiye'nin İthalat Fonksiyonu Katsayılarındaki Değişimin İncelenmesi. Dumlupınar Üniversitesi Sosyal Bilimler Dergisi, Sayı 9, 67-80.

Arslan, C.B., Çaşkurlu, E., (2016). Transatlantik Ticaret Ve Yatırım Anlaşmasının Türkiye'de İhracatçı Şirketlerin Dış Borcuna Ve İstihdama Etkisi. International Congress on European Union Relations, Economics, Finance and Econometrics (EUREFE'16) 14-16 July 2016, Aydın.

Atılgan, T., Kanat, S., (2007). The Effects of Free Trade Agreements on Turkish Economy. Sosyo Ekonomi, 1, 99-108.

Aydın, A.K., (2004). Serbest Ticaret Anlaşmalarının Yeri ve Türkiye'nin Dış Ticaretinin Geliştirilmesindeki Önemi. http://www.mfa.gov.tr/serbest-ticaret-anlasmalarinin-yeri-ve-turkiye Erişim 12.12.2017.

Bayar, G., (2017). Türkiye’nin Avrupa Birliği Ülkelerinden ve Dünyadan Sanayi Ürünleri İthalatı: Karşılaştırmalı Panel Veri Analizi. Ege Akademik Bakış, Cilt 17, Sayı 2, 163-178.

Czarny, E., Felbermayr, G., (2017). How Would a TTIP Affect Central and Eastern Europe?. CESifo Forum 1, Volume 18, 3-4.

Çelebi, I., (2013). ABD ve AB’nin Yeni Ekonomik İşbirliği Stratejileri ve Türkiye’ye Etkileri. Marmara Avrupa Araştırmaları Dergisi, Cilt 21, Sayı: 2, 217-229. 
Doğan, A., Uzun, A., (2014). Serbest Ticaret Anlaşmalarının Türkiye'nin Dış Ticaretine Etkileri. C.Ü. Iktisadi ve İdari Bilimler Dergisi, Cilt 15, Sayı 1, 325-344.

Düzenli, C., (2006), Dogrudan Yabancı Yatııımların Gelişmekte Olan Ülke Ekonomilerine Etkileri: Serbest Bölgeler Açısından Bir Analiz, T.C. Süleyman Demirel Üniversitesi Sosyal Bilimler Enstitüsü Iktisat Anabilim Dalı Isparta, Yayımlanmamış YL Tezi.

Erem, O., (2016). AB-Kanada Serbest Ticaret Anlaşması Türkiye'yi nasıl etkileyecek?. BBC Türkçe 4 Kasım 2016, http://www.bbc.com/turkce/haberler-dunya-37859376 Erişim 01.02.2018.

Erkan, B., Yıldırımcı, E., (2015). Economic Complexity and Export Competitiveness: The Case of Turkey. World Conference on Technology, Innovation and Entrepreneurship, Procedia - Social and Behavioral Sciences, 195, 524 - 533.

Ertürk, E., (2010), Uluslararası Iktisat, Alfa Yayınları, İstanbul.

European Union, Council Regulation (EEC) No 2913/92 of 12 October 1992; Chapter 3, Section 1, Article 166.

Felbermayr, G., Aichele R., (2015). How to make TTIP inclusive for all?. Ifo Institute for Bertelsmann Stiftung, Munchen.

Felbermayr, G., (2016). Economic Analysis of TTI. Ifo Working Paper No. 215, Ifo Institute - Leibniz Institute for Economic Research at the University of Munich.

Fontagne, L., Foure, J., Keck, A., (2017). Simulating World Trade in the Decades Ahead: Driving Forces and Policy Implications. The World Economy, 36-55.

Gereffi, G., Luo, X., (2004). Risks and Opportunities of Participation in Global Value Chains. The World Bank Policy Research Working Paper 6847.

Güllü, I., Kılıç, N.O., Şanlıoğlu, O., (2017). Evaluation of the EU-Canada comprehensive economic and trade agreement (CETA) in terms of Turkish foreign trade. Journal of Economics. Finance and Accounting (JEFA), V.4, Iss.3, 275-281.

Güllü, İ., (2014). AB-ABD Serbest Ticaret Anlaşması Sürecine Türkiye-AB Gümrük Birliği Anlaşması Özelinde Bir Bakış. Bilge Strateji, Cilt 6 , Sayı 11, 89-106.

Güngör, K., Ders Notları: Serbest Bölgeler, http://www2.aku.edu.tr/ kgungor/dersnotu.htm, Erişim 20.10.2015.

Hasanov, M., Macit, F., (2015). TTIP Anlaşmasının Türkiye Ekonomisine Olası Etkilerinin Analizi. Hazar Stratejik Araştırmalar Enstitüsü.

Hasanov, M., (2014), “Türkiye'nin Stratejik Hedefi: İthalata Olan Bağımlılığın Azaltılması”, Hazar Strateji Enstitüsü.

http://rtais.wto.org/UI/PublicAllRTAList.aspx

http://www.orgtr.org/tr/serbest-ticaret-anlasmasi-sta-imzaladigimiz-ulkeler-ve-yururluk-tarihleri

İhracatçı Eğilim Araştırması, (2015), 2015 1. çeyrek sonuçları, İstanbul.

Johnson, R.C., (2014). Five Facts about Value-Added Exports and Implications for Macroeconomics and TradeResearch. The Journal of Economic Perspectives, Vol. 28, No. 2, 119-142.

Karagöz, A., (2017). An Econometric Analysis for Turkey and the European Union Customs Union. Graduate Faculty of North Carolina State University, Raleigh, North Carolina, Unpublished Master Thesis.

Karluk, R., (1998), Uluslararası Ekonomi, Bursa.

Kılıç, E., Yıldırım, K., (2015). Sektörel Reel Döviz Kuru Oynaklığı İthalat Hacmini Etkiler Mi? Türkiye Üzerine Bir Uygulama. Dumlupınar Üniversitesi Sosyal Bilimler Dergisi, 43. Sayı, 192-199.

Kırışcı, K., (2013). Turkey and the Transatlantic Trade and Investment Partnership. Turkey Project Policy Paper, The Center on the United States and Europe at Brookings, Number 2.

Kocamaz, S., (2017). Transatlantik Ticaret ve Yatırım Ortaklığı Antlaşması'nın Dünya Ticaretine ve Türkiye Ekonomisi Üzerindeki Etkisi. Ege Strategic Research Journal, 6 (2), $31-56$

Koç, S., Sarısoy, İ., (2012). The Effect of FDI on Foreign Trade: A Panel Analysis. Eskişehir Osmangazi Üniversitesi IiBF Dergisi, 7(1), 187-210. Koçtürk, M., Kocaefe, A., (2014). Serbest Ticaret Anlaşmalarının Türk Dış Ticareti Üzerine Etkileri. Tarım Ekonomisi Dergisi, 20(2), 65-77.

Majchrowska, E., (2017). The trade aspects of the transatlantic cooperation between the EU, the USA and Canada. Krakowskie Studia Międzynarodowe, 2, 135-160.

Merkez Bankası, Elektronik Veri Destek Sistemi, https://evds2.tcmb.gov.tr/index.php?/evds/serieMarket/collapse_18/5003/ Erişim 01.02.2018

Mıroudot, S., Yamano, N., (2013). Towards the Measurement of Trade in Value-Added Terms: Policy Rationale and Methodological Challenges, in Trade in Value Added: Developing New Measures of Cross-Border Trade, edited by Aaditya Mattoo, Zhi Wang And Shang-Jin Wei, 17-39. 
New Zealand Foreign Affairs and Trade Trade / Free trade agreements, https://www.mfat.govt.nz/en/trade/free-trade-agreements/freetrade-agreements-concluded-but-not-in-force/cptpp/tpp-and-cptpp-the-differences-explained/ Erişim 01.02.2018.

OECD-WTO: Statistics on Trade in Value Added, http://www.oecd-ilibrary.org/trade/data/oecd-wto-statistics-on-trade-in-valueadded tiva-data-en Erişim 01.02.2018.

Öztelli, E.O., (2016), AB Ortak Ticaret Politikasına Uyumun Hızlandırılmasında Türkiye'nin Yeni Nesil Serbest Ticaret Anlaşmalarının Rolü, T.C. Ankara Üniversitesi Sosyal Bilimler Enstitüsü AB ve Uluslararası Ekonomik İlişkiler (Uluslararası Iliş̧kiler) Anabilim Dalı, Basılmamış Doktora Tezi, Ankara.

Öztürk, L., (2013). Serbest Bölgelerin Geleceği: Türkiye Açısından Bir Değerlendirme. Uluslararası Yönetim İktisat ve İşletme Dergisi, Cilt 9, Sayı 19, 75-86

Serbest Bölgeler Uzmanlık Tezi, (2003),

http://www.abuzmanlari.org.tr/web/Yay\%C4\%B1nlar/Uzmanl\%C4\%B1kTezleri/tabid/70/language/tr-TR/Default.aspx Erişim 01.02.2018.

Sülün, D., (2017). Lizbon Antlaşması'nın Avrupa Birliği Ortak Ticaret Politikasına Etkileri ve Transatlantik Ticaret ve Yatırım Ortaklığı Antlaşması Vaka Çalışması. Marmara Avrupa Araştırmaları Dergisi, Cilt 25, Sayı: 1, 103-132.

T.C. Ekonomi Bakanlı̆ı̆, Serbest Bölgeler Portalı Verileri, https://www.ekonomi.gov.tr/portal/content/conn/UCM/uuid/dDocName:EK$\underline{070995}$ Erişim 01.02.2018.

T.C. Ekonomi Bakanlığı, Serbest Bölgeler Portalı, www.ekonomi.gov.tr/portal/faces/home/vatirim/serbestBolgeler/istatistikler Erişim 01.02.2018.

T.C. Ekonomi Bakanlığı, Serbest Ticaret Anlaşmaları Portalı,

http://www.ekonomi.gov.tr/portal/content/conn/UCM/path/Contribution\%2OFolders/web Erişim 01.02.2018.

Timmer, M.P., Erumban A.A., Los B., Stehrer R., Vries G.J., (2014). Slicing Up Global Value Chains. Journal of Economic Perspectives, 28(2), $99-118$.

Tunalı, D., Aytekin A., (2017). Türkiye Dış Ticaretinin Kümeleme Analizi ile İncelenmesi. Eskişehir Osmangazi Üniversitesi iïBF Dergisi, C. 12, S. 3, 103-116.

Türkcan, K., Pişkin E., (2014). The Efects of the Trade Agreements on the Dynamics of Turkey's Export: Extensive and Intensive Margins. MPRA Paper No. 59841.

Türkiye İstatistik Kurumu, Dış Ticaret İstatistikleri, 2017, http://www.tuik.gov.tr Erişim 01.02.2018.

Türkiye İstatistik Kurumu, Diş Ticaret istatistikleri, 2017, http://www.tuik.gov.tr/PrelstatistikTablo.do?istab id=624; http://www.tuik.gov.tr/PrelstatistikTablo.do?istab id=625 Erişim 01.02.2018.

Türkiye İstatistik Kurumu, Dış Ticaret Istatistikleri, 2017, http://www.tuik.gov.tr/PrelstatistikTablo.do?istab id=1343 Erişim 01.02.2018.

Ünsal, E., (2005), Uluslararası Iktisat, İmaj Yayınları, Ankara.

Üstün, N., (2013). AB - ABD Ticaret ve Yatırım Anlaşması ve Türkiye'ye Etkileri. Konya, http://www.kto.org.tr/arastirma-ve-bilgi-raporlari384s.htm Erişim 01.02.2018.

YIlmaz, K., (2011). The EU-Turkey Customs Union Fifteen Years Later: Better, Yet not the Best Alternative. South European Society and Politics, Vol. 16, No. 2, 235-249. 